\title{
United States v. Barker: Misapplication of the Reliance on an Official Interpretation of the Law Defense
}

In United States v. Barker, ${ }^{1}$ the Court of Appeals for the District of Columbia Circuit reversed the convictions of two participants in the infamous "Ellsberg break-m" and held that the defendants must be allowed to present a mistake of law defense. The district court judge had rejected the proposed defense that the defendants lacked the required mens rea due to a mistake of law, and the jury had convicted the defendants of conspiracy to violate the civil and constitutional rights of psychiatrist Louis J. Fielding by burglarizing his office. ${ }^{2}$ On appeal, Judges Wilkey and Merhige agreed that the defendants should have been permitted to introduce evidence of their mistaken belief im the legality of their actions, but did not agree on the exception to the mistake of law doctrine allowing admission of the evidence in this case. Judge Wilkey voted to reverse because the activity of defendants Barker and Martimez was excusable if based on a reasonable, good faith reliance on the apparent authority of a government official. ${ }^{3}$ Judge Wilkey analogized this defense to two recognized exceptions to the general rule that mistakes of law are not defenses to criminal prosecution: $^{4}$ the defense of reliance on an official interpretation of the law and the call-to-aid defense. ${ }^{5}$ Writing separately for reversal, Judge

1. 546 F.2d 940 (D.C. Cir. 1976).

2. 18 U.S.C. $§ 241$ (1970). This section provides:

If two or more persons conspire to injure, oppress, threaten, or intimidate any citizen in the free exercise or enjoyment of any right or privilege secured to him by the Constitution or laws of the Umited States, or because of his having so exercised the same: or

If two or more persons go in disguise on the highway, or on the premises of another, with intent to prevent or hinder his free exercise or enjoyment of any right or privilege so secured-

They shall be fined not more than $\$ 10,000$ or imprisoned not more than ten years, or both; and if death results, they shall be subject to imprisonment for any term of years or for life.

3. According to Judge Wilkey, the district court's decision not to recognize a mistake of law defense led to two critical legal errors: (1) the defendants were precluded froin offering complete evidence of the reasonableness of their belief in E. Howard Hunt's authority; and (2) the court refused to give the defendants' proposed jury instructions setting forth their theory of the case. 546 F.2d at 944 .

4. See Part IIIA infra.

5. Judge Wilkey imphicitly places all three of these defenses under the broad heading of assisting a government official in the performance of a governmental task. $546 \mathrm{~F} .2 \mathrm{~d}$ at $948-49$. 
Merhige found Judge Wilkey's proposed defense of reliance on apparent authority to be too broad and applied the narrower defense of reliance on an official interpretation of law. ${ }^{6}$ Applying this defense, Judge Merhige considered the facts sufficient to have required submitting the question of defendants' reasonable reliance on an official interpretation of law to the jury. Judge Leventhal dissented and argued against recognizing the defendants' claim of reliance on the apparent authority of a minor government official as an exception to the general mistake of law rule. $^{7}$

In finding exculpatory defendants' reliance on the apparent authority of a minor government official who liad no responsibility for interpreting, administering, or enforcing the law, Barker contradicts recent codifications, prior case law, academic commentary, and important policies justifying exceptions to the general mistake of law rule. Fairness requires a mistake of law defense to protect those persons who in good faith rely on a government official to authorize certain conduct and who also reasonably believe such conduct is lawful. Important policy considerations, however, deinand witls equal force that this protection be limited to those persons who receive approval for their conduct from the appropriate government official-the official with legal authority to interpret, administer, or enforce the law at issue. The defendants in Barker did not satisfy this limited defense. By permitting these defendants to claim the mistake of law defense, the court of appeals lias impaired the efficacy of the general rule of ignorantia juris non excusat. $^{8}$

\section{I}

\section{The Factual Context ${ }^{9}$}

The case arose from atteinpts by the White House in 1971 to investigate leaks of classified inforination, in particular, Daniel Ellsberg's public disclosure of the "Pentagon Papers." 10 A group called the "Spe-

6. 546 F.2d at 954 .

7. Id. at $968-69$.

8. The word "ignorantia" in the maxims ignorantia facti excusat and ignorantia juris non excusat has been translated as both "ignorance" and as "mistake." A few courts and commentators have attempted to distinguish the two words, defining "ignorance" as a total lack of knowledge of the subject matter and "mistake" as an erroneous conclusion caused by insufficient knowledge. See, e.g., Hutton v. Edgerton, 6 S.C. 485, 489 (1875), and Keedy, Ignorance and Mistake in the Criminal Law, 22 HARv. L. REv. 75, 76 (1908). Generally, however, the courts have not recognized a distinction between these two terms. This Note will employ the term "mistake."

9. This summary of the facts comes from United States v. Barker, 546 F.2d 940, 943-44, 958-60 (D.C. Cir. 1976) (Wilkey, J.; Leventhal, J., dissenting); United States v. Ehrlichman, 546 F.2d 910, 914-16 (D.C. Cir. 1976), cert. denied, 429 U.S. 1120 (1977); United States v. Liddy, 542 F.2d 76, 78-79 (D.C. Cir. 1976); United States v. Barker, 514 F.2d 208, $252-53$ (D.C. Cir. 1975) (en banc) (Wilkey, J., dissenting), cert. denied, 421 U.S. 1013 (1975).

10. See generally New York Times Co. v. United States, 403 U.S. 713 (1971). 
cial Investigations" or "Room 16" unit was formed for the purpose of conducting these imvestigations. ${ }^{11}$ This unit operated under the general supervision of John Ehrlichman, the Assistant to the President for Domestic Affairs. After Ellsberg's psychiatrist, Louis J. Fielding, refused to be interviewed by FBI agents, the unit planned a covert operation to obtain copies of Ellsberg's medical records. ${ }^{12}$

Defendants Barker and Martimez both had worked as covert agents for the CIA. E. Howard Hunt, one of the members of the Room 16 unit and a career CIA agent, had been one of Barker's immediate supervisors during the Bay of Pigs invasion. Barker and Hunt had reestablished personal contact in April 1971. ${ }^{13}$

In August 1971, Hunt told Barker that he was working for an organization-above the FBI and CIA-that lad been created in the White House " "because the FBI was tied by Supreme Court decisions . . . and the Central Intelligence Agency didn't have jurisdiction in certain matters." "14 Hunt asked Barker to become "operational" again and to help conduct a surreptitious entry to obtain national security information on " "a traitor to this country who was passing . . . classified information to the Soviet Embassy." "15 Hunt described the "traitor" as "'a possible Soviet agent." "16 Barker agreed to participate im the operation and recruited Eugemo Martinez, ${ }^{17}$ who unlike Barker was still on CIA retainer, and Fehpe De Diego ${ }^{18}$ to assist in the operation.

On September 2, 1971, Hunt and G. Gordon Liddy, another inember of the Room 16 unit, met with Barker, Martimez, and De Diego im a Beverly Hills hotel. Hunt told the defendants of the plan to enter Dr. Fielding's office and to photograph the file of one of his patients. Authorization for the entry and search was not discussed at this ineeting.

On the evening of September 3, 1971, the defendants broke into

11. This group gradually became known as the "plumbers" since its mission was to stop leaks of classified information. United States v. Haldeman, 559 F.2d 31, 55 n.16 (D.C. Cir. 1976), cert. denied, 431 U.S. 933 (1977).

12. Although Ehrlichman contended at his trial that he did not authorize the break-in, the jury found that he had authorized the burglary. Uvited States v. Ehrlichman, 546 F.2d at 915.

13. Hunt gave Barker his unlisted White House telephone number. Thereafter, Hunt coininumicated with Barker on White House stationery and inet with him once in The Executive Office Building.

14. 546 F.2d at 959 (Leventhal, J., dissenting).

15. Id. at 943 (Wilkey, J.).

16. Id.

17. Barker passed on to Martinez the same information Hunt lad given to him. Id.

18. The district court dismissed the indictment against De Diego on the ground that the government could not show that its case was not tainted by the use of immunized testimony. Although the court of appeals reversed the trial court's order to dismiss, United States v. De Diego, 511 F.2d 818 (D.C. Cir. 1975), the Special Prosecutor cliose not to pursue the prosecution. 546 F.2d at 959 n.3 (Leventhal, J., dissenting). 
Dr. Fielding's office, ${ }^{19}$ but did not find a file on Ellsberg. The burglary was not revealed to the public until April 27, 1973. ${ }^{20}$ On March 7, 1974, Barker and Martinez were indicted under 18 U.S.C. $\$ 241$ and charged with conspiracy to violate the fourth amendment rights of Dr. Fielding by unlawfully entering and searching his office.

At trial, Barker and Martinez proposed a jury instruction ${ }^{21}$ charging that a reasonable, good faitl reliance by the defendants on the apparent authority of Hunt to authorize their actions would be a mistake of fact adequate to negate the specific intent for conspiracy required for conviction under section $241 .{ }^{22}$ The trial court judge rejected this proposal and instead gave the jury a two-part instruction statimg that (1) an honest belief by the defendants that a valid warrant had been issued would be classified as a mistake of fact and would excuse the defendants for lack of criminal intent, and (2) a belief by the defendants, that despite the absence of a warrant, the break-in was legal would be a mistake of law and would not be exculpatory. ${ }^{23}$ Thus, in order to convict, it was ouly necessary for the jury to find that the purpose of the conspiracy was to enter and search Dr. Fielding's office without a warrant and without his consent and that such a search was for govern-

19. Although the primary plan called for entering without using force, the defendants found they had to break the lock on the office door and use a crowbar to open the file cabinets. The defendants wore surgical gloves during their search to avoid leaving fingerprints, and before leaving the office Barker and Martinez spilled pills on the floor to make it appear that an addict had entered searching for drugs. 546 F.2d at 960 (Leventhal, J., dissenting).

20. The break-in became public knowledge when the judge presiding over the government's prosecution of Daniel Ellsberg for his role in the release of the Pentagon Papers read in open court a Justice Department memorandum revealing the burglary. N.Y. Times, April 28, 1973, \& A, at 1, col. 4. See also United States v. De Diego, 511 F.2d 818, 827-28 n.3 (D.C. Cir. 1975) (McGowan, J., dissenting), for more information regarding the "discovery" of the Ellsberg break-in.

21. Defendants' proposed instruction read in part:

[S]ince specific intent is an essential element of this offense, if a defendant acted out of a good faith behef that what he was doing was with authority of law and not in violation of the law, that is a defeuse to the crime charged, even if that sincere belief that his actions were lawfully authorized was erroneous.

This is not to say that a mistake of law on the part of a defendant would constitute a defense to the crime charged. Neither ignorance of the law nor mistake of law would excuse the criminal conduct in this case. However, if actions are taken as the result of mistake of fact, as opposed to ignorance or a mistake of law, then the defendant has not formed the requisite intent for the crime charged. Accordingly, if you find that a defendant beheved he was acting out of a good faith reliance upon the apparent authority of another to authorize his actious, that is a defeuse to the charge in Count $I$, provided you find that such a mistake by a defendant was made honestly, sincerely, innocently and was a reasonable mistake to make based upon the facts as that defendant perceived them.

546 F.2d at 961-62 n.15 (Leventhal, J., dissenting).

22. See generally Judge Wilkey's discussion in Barker, 546 F.2d at $945-46$, and in Ehrlichman, 546 F.2d at 917-29. According to Judge Wilkey, the "specific intent" requirement of $\$ 241$ does not require proof that an accused acted with the subjective awareness that his conduct was unlawful. Rather, it is sufficient that the defendant intentionally perforned acts that clearly would have been in violation of federal law, absent any other defense. The court found that the "specific intent" requirement was satisfied in both Ehrlichman and Barker.

23. 546 F.2d at 945 n.6 (Wilkey, J.). 
mental rather than purely private purposes. ${ }^{24}$

On appeal, the defendants attempted to clarify their trial claim of a good faith, reasonable reliance on Hunt's apparent authority by asserting that their mistake was a combination of fact and law: "The mistake of fact was the belief that Hunt was a duly authorized governinent agent; the mistake of law was that Hunt possessed the legal prerequisites to conduct a search-either probable cause or a warrant." ",25 The basis of the defense presented by Barker and Martinez was that their conduct should be excused because they lacked the rcquired mens rea as a result of a "mistake of fact mixed with law."26

\section{II}

\section{Mistake of Fact and Mistake of Law}

\section{A. The General Rule}

Generally, an lonest mistake of fact excuses otherwise unlawful conduct if it negates the mens rea required by the definition of the crime and if the acts would be lawful if the facts were as the defendant believed. ${ }^{27}$ This rule follows from the fundamental legal principle that requires culpability or blameworthiness before inposing criminal sanctions. ${ }^{28}$

A mistake of law, on the other hand, generally is not a defense to a criminal charge, even when it is made both reasonably and honestly. ${ }^{29}$ That a mistake of law does not excuse when it negates mens rea conflicts with the principle requiring culpability before inuposing punishment. Several arguments support this mistake of law rule. ${ }^{30}$ Perhaps the

24. Id. at 944 .

25. Id. at 946 (quoting the brief of appellant Barker at 31-32).

26. Id. at 945 .

27. See, e.g., Model Penal Code \$ 2.04(1) (P.O.D. 1962); W. LAFAve \& A. ScotT, CRIMINal Law § 47, at 357 (1972); G. Williams, Criminal Law: The General Part \$ 71, at 201 (2d ed. 1961); and Keedy, supra note 8, at 84.

Some commentators belive that a mistake of fact must be reasonable as well as committed in good faith in order to be exculpatory. See, e.g., R. PERkIns, Criminal Law 939-40 (2d ed, 1969); I R. ANDERson, WharTon's CRIMINal LAW AND PROCEDURE § 157, at 382 (1957); and Houlgate, Ignorantia Juris: A Plea for Justice, 78 ETHIcs 32 (1967). See also United States v. Barker, S14 F.2d 208, 235-36, 243 (Bazelon, C.J., concurring; MacKinnon, J., dissenting). This view has been correctly criticized as both "contrary to fundamental principles" and "plainly unjust," for "[i]f the defendant, being mistaken as to material facts, is to be punished because his mistake is one which an average man would not make, punishment will sometimes be inflicted when the criminal mind does not exist." Keedy, supra note 8, at 84.

28. See generally H. PACker, The Limits of THE CRiminal Sanction 112-21 (1968); Hall \& Seligman, Mistake of Law and Mens Rea, 8 U. CHI. L. REv. 641 (1941).

29. See generally Lambert v. California, 355 U.S. 225, 228 (1957) (quoting Shevlin-Carpenter Co. v. Minnesota, 218 U.S. 57, 68 (1910)); Hall \& Sehgman, supra note 28; and Keedy, supra note 8. Of course, a mistake of law will excuse if one of the elements of the offense is the knowledge of illegality. See W. LAFAvE \& A. ScOTT, supra note 27, at 356-57; and Hall \& Sehgman, supra note 28 , at 641 .

30. See, e.g., Bolgar, The Present Function of the Maxim Ignorantia Juris Neminem Ex- 
most persuasive maintams that society's interest in making the public know the law outweighs its interest in individual fairness. ${ }^{31}$ Proponents of this view recognize the sometimes harsh results of this general rule,

cusat-A Comparative Study, 52 Iowa L. Rev. 626 (1967); Brett, Mistake of Law As a Criminal Defense, 5 MELB. U. L. REV. 179 (1966); Hall, Ignorance and Mistake in Criminal Law, 33 IND. L. J. 1 (1957); Hall \& Seligman, supra note 28; Houlgate, supra note 27; Keedy, supra note 8; O'Connor, Mistake and Ignorance in Criminal Cases, 39 MoD. L. Rev. 644 (1976); Perkins, Ignorance and Mistake in Criminal Law, 88 U. PA. L. REv. 35 (1939); Ryu \& Silving, Error Juris: A Comparative Study, 24 U. CHI. L. REv. 421 (1957).

A "rationale" that was offered at one time in support of the mistake of law doctrine is expressed by the familiar phrase "everyone is presumed to know the law." This "explanation" is really nothing more than a restatement of the rule in different terms rather than a rationale in support of its validity. It is doubtful that this presumption ever had much validity, see G. WILLIAMS, supra note $27, \S 102$, at $289-90$, and it is umiversally rejected today as unrealistic in light of the explosion of statutes and case law in this century. Comment, Applying Estoppel Principles in Criminal Cases, 78 Yale L.J. 1046, 1054 (1969).

A second explanation for the deviation of the mistake of law doetrine from the general theory of inens rea can be characterized as an argument of "practical necessity." As expressed by Austin, this view articulates the pragmatic fear that if a mistake of law defense were allowed the courts would be inundated by such pleas, thereby presenting the factfinder with confusing and unsolvable issues which would clog the wheels of justice. J. AUstin, LeCTURES ON JURISPRUDENCE 498 ( $3 \mathrm{~d}$ ed. 1869). Criticism of this rationale has generally been along two lines: (1) the issue of knowledge of the law is no inore difficult to adjudicate than other jury questions, and (2) evcn if the issues poses proof problems, the remedy for such an inherent difficulty of proof is to place the burden of proof of establishing ignorance of the law on the accused. See O. W. HoLMES, THE COMMON LAw 48 (1881); and G. Williams, supra note 27, § 102, at 291. But see Hall \& Seliginan, supra note 28 , at $647-48$.

A third argument, as formulated by Jerome Hall, for not recognizing a mistake of law defense is that the defense would contradict "the essential requisites of a legal system, the implications of the principle of legality." Hall, Ignorance and Mistake in Criminal Law, 33 IND. L.J. 1, 19 (1957). Under Hall's analysis, the rule of law contains three major elements: (1) rules of law express objective meanings; (2) the "competent officials" shall, after a prescribed procedure, declare what those meanings are; and (3) only those official interpretations are binding. Id. According to Hall,

[t]o permit an individual to plead successfully that he had a different opinion or interpretation of the law would contradict the above pestulates of a legal order. For there is a basic incompatibility between asserting that the law is what certain officials declare it to be . . . and asserting, also, that those officials must declare it to be . . . what defendants or their lawyers believed it to be. A legal order implies the rejection of sucl contradiction. It opposes objectivity to subjectivity, judicial process to imdividual opinion, official to lay, and authoritative to non-authoritative declarations of what the law is.

Id. Hall's analysis has been criticized for failing to distinguish between the concepts of justification and excuse and thus confusing the "question of the culpability of the accused with a question of the legality of his deed." Houlgate, supra note 27, at 39. See also Fletcher, Individualization of Excusing Conditions, 47 So. CAL. L. Rev. 1269, 1298-1302 (1974); Ryu \& Silving, supra, at 433.

Hall also suggests that another rationale for ignorantia juris neminem excusat can be expressed in terms of the "ethical pohcy ... that the criminal law represents ccrtain moral principles: to recognize ignorance or mistake of the law as a defense would contradict those values." Hall, supra, at 26. For a criticism of Hall's views that legality cannot be separated from inorality in a system of criminal law, see Houlgate, supra note 27 , at 40 .

31. O. W: Holmes, THE COMmon LAW 48 (1881). Justice Holunes' view that the purpose of the criminal law is "to make men know and obey" has been criticized as "contrary to the basic democratic principle that man should not be used as a means to an end," Ryu \& Silving, supra note 30 , at 433 , and as being simply not valid, Hall, supra note 30 , at $17-18$. But see Hall \& Seligman, supra note 28 , at 648-49. 
but justify it by emphasizing its value in destroying a person's incentive to remain ignorant of the law.

Various informal mechanisms in the criminal justice systein-prosecutorial discretion, jury nullification, judicial sentencing, and executive cleinency-moderate the sometimes harsh results of strict application of the general mistake of law rule. ${ }^{32}$ The tension created by the clash between individual justice and the "general good" also has been mitigated by the recognition that other policy considerations require that certain exceptions to the mistake of law doctrime be inade. ${ }^{33} \mathrm{~A}$ mistake of law defense where the defendant did everything possible under the circumstances to ascertain the law is consistent with, if not coinpelled by, the goal of inaking people know and obey the law. ${ }^{34}$ In certain situations, therefore, a defense based on a mistake of law is allowed if the mistake is reasonable and inade in good faith, and if strong policy reasons justify recognizing a defense. ${ }^{35}$

\section{B. Classification as Mistake of Fact or Mistake of Law}

In summary, a defendant's plea of mistake is exculpatory if it involves either an honest mistake of fact or an honest and reasonable mistake of law where strong policy reasons compel the recognition of a defense. Because the requirements of a mistake of fact defense are less strict than those of the mistake of law defense, classification of a mistake as one of fact or of law often determines the success or failure of an accused's defense. A mistake cannot always be characterized easily as either one of fact or of law. The attempts to classify the mistake in Barker illustrate the difficulty of the task.

Glanville Willianıs offers a useful approach for distinguishing law and fact: "[a] fact is something perceptible by the senses, while law is an idea in the minds of men." ${ }^{36}$ The classic example used to draw the distinction between mistakes of fact and law poses little difficulty under Williains' analysis. A man who grabs another's umbrella upon leaving a restaurant under the mistaken belief that it is the sane umbrella that the man brought with him into the restaurant has inade a mistake of fact. On the other hand, if the inan takes another's umbrella under the mistaken belief that prior dealings had vested ownership of this partic-

32. See notes $120-23$ infra and accompanying text.

33. R. PERKINS, supra note 27, at 925 .

34. Houlgate, supra note 27, at 38; Brett, supra note 30, at 195.

35. See generally the artieles cited in note 30 supra and cases cited therein.

36. G. WILLIAMS, supra note 27, § 100, at 287. Jerome Hall distinguishes between "law" and "fact" in the following terms: "Law is expressed in distinctive propositions, "whereas facts are qualities or events occurring at definite places and times. Facts are particulars directly sensed in perception and introspection. Legal rules are generalizations; they are not sensed, but are understood in the process of cognition." Hall, supra note 30, at 14. 
ular umbrella in him, this would be a mistake of law. ${ }^{37}$ As the situations become more complex, however, the border between fact and law becomes blurred.

Williams attempts to clarify his method of analysis by offering examples of its application with regard to marriage and ownership:

A mistake as to whether a marriage has been celebrated may be either a mistake of fact or a mistake of law. It is a mistake of fact if no ceremony has been performed; a ceremony is a fact, of which a cinematograph picture could be taken. But the mistake is one of law if, though the cereinony has been performed, there is a misunderstanding of the rules of law governing the validity of the ceremony. In the same way, a mistake as to ownership may be either a mistake as to whether a deed of conveyance has been executed, which is a question of fact, or a mistake as to the law of property in its impact on a particular deed of conveyance. Soinetimes the two are blended. Thus $A$ may be informed, wrongly, that $B$ is the owner of certain property, and inay beleve the information, without inquiring into $B$ 's title-deeds or into the law of property. $A$ 's mistake is here as to the net outcome of the operation of law and fact, without distinguishing between the two. Such a mistake as to mixed law and fact is frequently called a mistake as to private right, but this expression is also used to cover a pure mistake of law. ${ }^{38}$

This Note adopts the Williams metliodology for classifymg mistakes of fact and law.

\section{Classifying the Mistake in Barker}

On appeal, defendants asserted a defense based on both a mistake of fact (their belief that Hunt was a duly authorized government agent) and a mistake of law (their belief that Hunt possessed the legal prerequisites to conduct a search). ${ }^{39}$ Barker and Martimez characterized their mistake of law claim as consisting of two distimct parts-a belief that Hunt possessed either probable cause or a warrant. Defendants' alleged

37. See W. LAFAVE \& A. SCOTT, supra note 27 , at 357 . Because larceny is a crime that has as a necessary element the intent to steal the property of another, both of these mistakes would be exculpatory because the actor did not have the necessary "intent to steal" in either case.

38. G. Williams, supra note $27, \S 100$, at 287 . Keedy would also treat a situation involving the misapplication of law to facts as a mistake of law. Keedy, supra note 8, at 77 .

Professor Perkins uses a divorce example to illustrate the distinction between fact and law. According to Perkins, if the defendant knows the procedures that were taken in an effort to obtain a divorce and mistakenly believes such steps were sufficient, this would be a mistake of law. On the other hand, it would be a mistake of fact if the defendant mistakeuly relied upon mcorrect information to the effect that his spouse liad obtained a divorce. R. PERKINS, supra note 27, at 945. This example is nore properly treated as a mistake regarding the net outcome of the operation of law and fact. Such a mistake of mixed law and fact slould be analyzed, as Glanville Williams does, as a mistake of law. It inakes sense on policy grounds to mipose the mistake of law requirement of reasonableness on any mistake that has as one of its components a mistake of law.

39. 546 F.2d at 946 (Wilkey, J.) See generally Comment, Reliance on Apparent Authority as a Defense to Criminal Prosecution, 77 Colum. L. Rev. 775 (1977), for an additional analysis of defendants' proposed defense. 
behief that Hunt had probable cause to conduct a search is an example of mistake of law-Barker and Martinez were aware of some of the facts motivating the search, ${ }^{40}$ but they did not know whether these facts were legally sufficient to constitute probable cause. Such a fact-law combination should be classified as a mistake of law. ${ }^{41}$ The defendants apparently did not present any arguments about why such a mistake should be recognized as an exception to the general mistake of law rule and the court of appeals ignored this question. Both the parties and the court probably chose to ignore the issue because of the absence of policy reasons for allowing such a mistake of law as a defense. The court also may have chosen to ignore this claim because of defendants' failure to raise it during trial.

Defendants also characterized their behef that Hunt possessed a warrant as a mistake of law, ${ }^{42}$ but the trial court classified a behef in the existence of a valid warrant as a mistake of fact. A belief in the existence of a valid warrant, however, is inore accurately seen as a mistake regarding the net outcome of the operation of law and fact. Whether a warrant has been issued is a fact perceptible by the senses, but one who beheves in the existence of a valid warrant actually rehes on the opinion of a judge that legally sufficient probable cause exists to conduct a search. ${ }^{43} \mathrm{~A}$ mistaken belief that a search is legal because of a judicial determination later found to be invalid-an "idea in the mind"-is a mistake of law. Thus, a mistake as to the existence of a valid warrant is a mistake of mixed law and fact and is analyzed correctly as a mistake of law. ${ }^{44}$

The trial court's erroneous imstruction that an honest belief in the issuance of a valid warrant constitutes a mistake of fact, and thus exculpates, actually benefited the defendants because a mistake of fact defense requires only a good faith belief, while a mistake of law defense demands both good faith and reasonableness. ${ }^{45}$ Defendants, therefore, should not have complained about this instruction. Moreover, despite broad leeway to explain their motives, ${ }^{46}$ defendants did not contend at trial that they believed that a warrant had been issued..$^{47}$ Nor did the jury conclude that the defendants believed that a warrant had been is-

40. See Part I supra.

41. See note 38 and accompanying text supra.

42. Implicit in this assertion is a belief that the warrant was valid, ie., that it was issued following a showing of legally sufficient probable cause, because without such a belief dcfendants would not satisfy the good faith belief in the legality of the conduct required by both the mistake of fact and the mistake of law defenses.

43. See notes 99-101 and accompanying text infra for a discussion of the so-called "executive" warrant.

44. See note 38 and accompanying text supra.

45. See tcxt accompanying notes 27,29 and 35 supra.

46. 546 F.2d at 972 (Leventhal, J., disseuting).

47. Id. at $960 \mathrm{n} .7,962$. 
sued because under the favorable jury instructions given at trial such a conclusion would have required acquittal. Consequently the defendants' warrant claim on appeal was without inerit.

Defendants claimed on appeal, as they had done at trial, that a good faith, reasonable rehance on the apparent authority of Hunt to authorize the Ellsberg break-in would be a mistake of fact and thus excuse. Defendants' contention that this mistake was one of fact is, however, analytically unsound. Rather, a mistaken belief in Hunt's authority is a mistake of law. In claiming that they beheved Hunt had authority, the defendants were saying they believed either one of two things: (1) that the necessary authority was vested in the office Hunt held so that he could personally authorize the break-in; or (2) that Hunt was a conduit of permission from a legitimate authority. A belief that Hunt's authority was derived from the office lie held fits squarely into Glanville Williams' defimition of a law as "an idea in the minds of inen." The defendants were not mistaken about whether Hunt held a position in the government; they knew his status. Rather, they were mistaken about the scope of his authority, i.e., whether he had legal power to approve the break-in. Similarly, a belief that power flowed to Hunt as a conduit for permission from solncone else, unaccompanied by information identifying that soneone with power or specifying the form in which a grant of authority was given, must be a mistake of law. It is analogous to Williams' example of a person mistakeuly believing, due to a failure to inquire into the existence of title deeds or into property law, that another is the owner of particular property. As Williams has pointed out, ${ }^{48}$ such a mistake as to the outcome of the operation of law and fact is correctly analyzed as a mistake of law..$^{49}$ Both the trial

48. See note 38 and accompanying text supra.

49. Defendants' characterization of their claim as a mistake of fact rather than a mistake of law probably can be attributed to the concurring and dissenting opimions written by Chief Judge Bazelon and Judge MacKinñon in a previous case also involving Barker and Martinez. In the prior case, also called United States v. Barker, 514 F.2d 208 (D.C. Cir. 1975) (en banc), cert. denied, 421 U.S. 1013 (1975) [hereinafter referred to as Barker-Watergate], defendants Barker and Martinez were on trial for their participation in the Watergate break-in. See generally United States v. Haldeman, 559 F.2d 31 (D.C. Cir. 1976) (en banc), cert. denied sub. nom. Mitchell v. United States, 431 U.S. 933 (1977). Because the majority in Barker-Watergate upheld the trial court's decision not to allow the defendants to withdraw their guilty pleas, the court did not have to consider whether the defendants had a valid defense based on their rehance on Hunt's authorization of the Watergate burglary, the same defense presented in the case under discussion here. See 514 F.2d at 216-18 for a discussion of the relevant facts in Barker-Watergate. Judges Bazelon and Mackinnon, however, did discuss the possibility of a "mistake" defense.

According to Chief Judge Bazelon, the distinction between fact and law in a situation mvolving the "application of legal principles to a particular factual situation" is "tenuous," 514 F.2d at 233 (emphasis deleted), and the distinction between mistakes of fact and law completely breaks down "when applied to the heavily fact-laden law of searcli and seizure or arrest . . . ." Id. at 235 n.36. Although he does refer to defendants' proposed defense of rehance on Hunt's authority as a mistake of law, Judge Bazelon also considered the case as one "where the distinction between fact and law is more 'nice than obvious' ...." Id. at 235. Judge Bazelon concluded that the pro- 


\section{judge and the three judges of the court of appeals agreed that mistake as to apparent authority should be classified as mistake of law.}

posed defense is "sufficiently close to a mistake of fact and sufficiently similar to a mistake as to civil law . . . that exculpation should be permitted," Id. at 235 n.38, but he reached this conclusion without discussing or analyzing any policy reasons that would justify the recognition of a defense of reliance on Hunt's authority.

One reason the distinction between mistake of fact and law is not critical for Judge Bazelon is that he apparently would require mistakes of fact to be both reasonable and in good faith, the same standard normally applied to mistakes of law. 514 F.2d at 235-36 n.39. Using the same standard for both types of mistake, however, denies the existence of the distinct policies underlying the two theories and inakes the designation of a mistake as either factual or legal a theoretical exercise which serves no substantive purpose. See notes 27-31 supra and accompanying text for a discussion of the general rule regarding mistakes of fact and law.

Judge MacKinnon, on the other hand, characterized defendants' proposed defense in BarkerWatergate as a mistake of fact- "a mistake as to the fact that all necessary authorization for their activities had been obtained." 514 F.2d at 241 (MacKinnon, J., dissenting) (einphasis added). Although in Barker-Watergate Barker and Martinez did not claim to believe that Hunt possessed either a judicial or an executive warrant, Judge MacKinnon nevertheless considered "[t]leir rehance on their superiors ... [to] be broad enough to include a belief that all necessary approval and authorization from government agencies, including the courts' had been obtained." Id. at 246. Judge MacKinnon, however, appeared to be putting behefs in the minds of Barker and Martinez that did not exist. Judge Skelly Wright, writing for the majority, expressly stated that neither Barker nor Martinez claimed "that any Government official-other than Hunt-ever spoke to thein about the Watergate operation or vouched for Hunt's 'authority' to undertake it." Id. at 217. In their respective opinions, both Chief Judge Bazelon and Judge Wilkey emphasized that Barker's and Martinez's defense really turned on their mistake as to Hunt's authority:

The defendants' mistake of law is largely a mistake as to Hunt's authority-ie., whether he had reasonable grounds for ordering the burglary.

Id. at 235 n.38 (Bazelon, C.J., concurring).

[The defendants'] willingness to enlist in the operation and help carry it out under these conditions derived primiarily from their staunch faith in one man, E. Howard Hunt.

Id. at 248 (Wilkey, J., dissenting).

[T]he appellants were ignorant of sufficient facts about the Watergate operation to argue that the break-in would have beeu legal if the facts had been as they beheved thein to be. They rehed not on what they knew about the operation, but on what they knew about Hunt. It was on his position and authority that their belief in the legality of their action was based.

Id. at 267 (Wilkey, J., dissenting). A mistake as to Hunt's authority is a mistake of law. See note 38 supra and accoinpanying text.

Both Chief Judge Bazelon's and Judge MacKinnon's erroneous analysis of defendants' proposed defense can be attributed to their misapplication of People v. Weiss, 276 N.Y. 384, 12 N.E.2d 514 (1938). In Weiss, a man purporting to be a detective and carrying a state secret service badge approached two citizens and requested their assistance in the arrest of another individual he described as a "murderer." Believing in good faith that they were performing their duty, the two citizens assisted the "detective" in the arrest and detention of the "murderer," who it later turned out was innocent. The two citizens were charged with kidnapping and at their trial were not allowed to offer a mistake of law defense based on their good faith behef that their conduct was legally authorized.

The New York Court of Appeals overturned their conviction in light of a New York statute requiring the accused kidnappers to have acted with the intent to act illegally. Chief Judge Bazelon considered Barker's and Martinez's defense to be "factually indistinguishable from [that presented in] Weiss." 514 F.2d at 235. Judge MacKinnon felt that Weiss was indistinguishable from [Barker-Watergate] and that Weiss "is the leading case for the proposition that a mistake as to the authority of an apparent official is a defense $\mathrm{m}$ a criminal case." Id. at 242. In addition to being distinguishable from Barker on statutory grounds, Judge MacKinnon's statement points out the critical factual difference between the two cases: Weiss was a case with an apparently appro- 


\section{III \\ APPLICATION IN BARKER OF EXCEPTIONS TO THE General Mistake of Law Rule}

Although the trial court correctly classified defendants' belief that Hunt was a duly authorized government agent as a mistake of law, it erred in instructing the jury that a mistake of law is absolutely no defense, because exceptions to the general rule have been recognized. ${ }^{50}$ Thus, if Barker and Martinez could have shown that their behef in Hunt's authority and in the lawfulness of their own conduct was both reasonable and made in good faith, they might have satisfied the requirements of one of the established exceptions to the general rule. If their mistake of law was both reasonable and made in good faith, and either inet the requirements of an establislied exception to the inistake of law rule or was sufficiently analogous to justify the recogniton of a new exception, then the defendants sliould have been acquitted. Both Judge Wilkey and Judge Merhige concluded that Barker's and Martinez's conduct qualified for a mistake of law defense.

\section{A. Judge Wilkey's Analysis}

Judge Wilkey cliaracterized Barker's and Martinez's proposed defense of reliance on Hunt's apparent autlority as an exainple of assistance to a government official in the performance of a governmental task. $^{51} \mathrm{He}$ drew analogies between their activity and two recognized exceptions to the general mistake of law rule: (1) a police officer who relies on a judicial warrant subsequently found to be defective; and (2) a private person summoned by a police officer to assist in making an unlawful arrest. ${ }^{52}$

priate official, a police detective laving the actual authority to call private citizens to his aid; Barker, on the other hand, was a case with an actual government official, E. Howard Hunt, who was claimed to have apparent authority to authorize the burglaries in the name of national security. In slort, Weiss is a call-to-aid type case-a recognized exception to the general mistake of law rule-the requirements of which the Barker defendants failed to satisfy. See note 52 infra for a discussion of the call-to-aid defense. Weiss actually involved two mistakes, one of fact and one of law. The mistake of fact was the defendants' good faith behef that the person posing as a detective was in fact sucl a government official. The mistake of law was the defendants' belief that the appropriate government official, a "detective," had summoned them to assist in the arrest and detention of a "murderer"-conduct that the defendants beheved in good faith to be legal.

50. See generally the articles cited in note 30 supra and cases cited therem.

51. 546 F.2d at $948-49$.

52. $I d$. at 948 . A citizen summoned by a police officer to assist in making an unlawful arrest falls within the call-to-aid exception. Judge Wilkey's characterization of Barker's and Martinez's conduct as similar to the call-to-aid defense probably can be attributed to Chief Judge Bazelon's concurring opinion in Umited States v. Barker, 514 F.2d at 227-37 and Zweibon v. Mitchell, 516 F.2d 594, 675-81 (D.C. Cir. 1975) (concurring and dissenting opinion), cert. denied, 425 U.S. 944 (1976). In Barker-Watergate, Chief Judge Bazelon concluded that Barker's and Martimez's 'mistake of law is largely a mistake as to Hunt's authority-i.e. whether he had reasonable grounds for ordering the burglary. As is iniplicitly suggested by the 'call-to-aid' rule . . . a mistake as to the 
The first analogy, a police officer's receiving and acting upon a defective warrant, illustrates the mistake of law defense known as reli-

lawful authority of a government official, which is what Hunt allegedly presented himself as, is sufficiently close to a mistake of fact and sufficiently similar to a mistake as to civil law . . . that exculpation should be permitted." 514 F.2d at 235 n.38. And in Zweibon v. Mitchell, Chief Judge Bazelon noted that "[t]he center of the reasoning of iny Barker opimion is that those who mistakenly believed that their actions were authorized are sufficiently similar to those who are called to the aid of an officer that the mistake of law defense of the latter recognized at common law should be extended to the former." 516 F.2d at $678 \mathrm{n} .12$.

Under the common law call-to-aid defense, a private citizen who is summoned by a peace officer to aid in effecting an arrest or in conducting a search is not hable for false arrest, false imprisoninent or trespass when the arrrest or search is subsequently found to have been unlawfnl. See, e.g., Firestone v. Rice, 71 Mich. 377, 38 N.W. 885 (1888) (arrest); Moyer v. Meier, 205 Okla. 405, 238 P.2d 338 (1951) (arrest); McMahan v. Green, 34 Vt. 69 (1861) (arrest); Annot., 29 A.L.R.2d 825 (1953) and cases cited therein (arrest); Reed v. Rice, 44 Ky. (2 J.J. Marsh.) (1829) (search). The Model Penal Code codified the call-to-aid rule in $\$ 3.07(4)$ (a) which states:

A private person who is summoned by a police officer to assist in effecting an unlawful arrest, is justified in using any force which he would be justified in using if the arrest were lawful, provided that he does not believe the arrest is unlawful.

Both the common law and the Model Penal Code's call-to-aid defenses are premised on the notions of duty and necessity. In many jurisdictions, failure to obey a summons to assist a public officer in making an arrest is a statutory offense. See, e.g., Peterson v. Robinson, $43 \mathrm{Cal} .2 \mathrm{~d} 690$, 277 P.2d 19 (1954); Mitchell v. Industrial Commission, 57 Ohio App. 319, 13 N.E.2d 736 (1936); Babington v. Yellow Taxi Corp., 250 N.Y. 14, 164 N.E. 726, 61 A.L.R. 1354 (1928); Moyer v. Meier, 205 Okla. 405, 238 P.2d 338, 29 A.L.R.2d 818 (1951). In addition to a duty to respond to an officer's summons for aid, both the courts and the Model Penal Code recognize that the necessity for prompt action prevents inquiry about justification. If citizens were obligated to make inquiries for their own protection, the purpose of statutes authorizing officiers to call private citizens to their assistance would be defeated. See, e.g., Reed v. Rice, 44 Ky. (2 J.J. Marsh.) (1829); Firestone v. Rice, 71 Mich. 377, 38 N.Y. 885 (1888); Moyer v. Meier, 205 Okla. 405, 238 P.2d 338, 29 A.L.R.2d 818 (1951); Model Penal Code § 3.07(4), Comment at 64-65 (Tent. Draft No. 8, 1958). Judge Wilkey also recognized the policy reasons on which the call-to-aid rule is based:

The citizen is under a legal obhigation to respond to a proper summons and is in no position to second-guess the officer's determination that an arrest is proper. Indeed, it is society's hope in recognizing the reasonableness of a citizen's mistake in this situation to encourage unhesitating compliance with a police officer's call.

S46 F.2d at 948 .

Granting Barker and Martinez a call to aid defense, however, satisfies neither of the policies underlying the defense. First, despite Judge Wilkey's semantic gymnastics, 546 F.2d at $948 \mathrm{n} .27$, Barker and Martinez did not have a duty to assist Hunt in the Ellsberg operation. Rather, Hunt "asked" Barker to become "operational" and he readily "agreed" to take part. Id. at 943 (Wilkey, J.). In his dissenting opinion, Judge Leventhal enphasized that "Barker and Martinez were under no tension of conflicting duties comparable to that experienced by a soldier or citizen respondimg to orders. They had and claim no obligation to aid Hunt." Id. at 967. Second, Barker and Martinez had sufficient time to inquire into the legality of their action, yet they never sought to determine Hunt's authority. Thus, the compelling policy interests justifying the call-to-aid defense are not present in Barker.

The Special Prosecutor correctly argued that Barker's and Martinez's conduct really came within Model Penal Code \& 3.07(4)(b), rather than \& 3.07(4)(a). 546 F.2d at 948 n.27. Section 3.07(4)(b) provides, in pertinent part:

A private person who ... not being summoned, assists a peace officer in effecting an unlawful arrest, is justified in using any force which he wonld be justified in using if the arrest were lawful, provided that (i) he believes the arrest is lawful, and (ii) the arrest would be lawful, if the facts were as he believes them to be.

Model Penal Code §3.07(4)(b) (P.O.D. 1962). Section 3.07(4)(b) would provide Barker and Marti- 
ance on an official interpretation of the law. ${ }^{53}$ According to Judge Wilkey, police officers are given a defense in this situation because it would be "neither fair nor practical to require police officers to meet a standard of care exceeding that exercised by a judge," 54 a governmental official "whose decisions we wish to see respected." J5 Judge Wilkey asserts that both justice and public policy would also be served if a private citizen who "acted at the behest of a government official . . . were allowed a defense based upon his reliance on the official's authority." 56 Under this analysis, the trial judge's jury instruction in this case-that a mistake about a search's legality was no excuse-would be justified only if Barker's and Martinez's reliance on Hunt's apparent authority were not analogous to a police officer's reliance on a judicial warrant. Under Judge Wilkey's test, the defendants' reliance would be analogous if they could show (1) facts justifying their reasonable reliance on Hunt's apparent authority and (2) a legal theory on which to base a reasonable belief that Hunt possessed such authority. ${ }^{57}$

In support of defendants' ability to satisfy the first prong of his test, Judge Wilkey noted that Barker and Martinez were recruited by a White House official, E. Howard Hunt, whom they knew as a longtime CIA agent. ${ }^{58}$ In addition, Hunt told them the operation concerned national security and a traitor who was passing classified inforination to the Russians. ${ }^{59}$ As former CIA operatives, both defendants were accustoined to working on a "need-to-know basis."60

To satisfy the second prong of his test, Judge Wilkey readily found a legal theory on which the defendants could have formed a reasonable belief that Hunt possessed authority for the break-in. According to Judge Wilkey, "plyysical entry for either an auditory or visual search for inaterial related to an agent or collaborator with a foreign nation, if authorized by the President or Attorney General, [arguably] would be valid under the Executive's constitutional foreign affairs powers." Thus, the judge found facts sufficient to raise a mistake of law defense and to require reversal of the convictions.

nez no relief because their search of Dr. Fielding's office would not have been lawful if the facts had been as they believed them to be.

53. See Part IVA infra.

54. 546 F.2d at 947.

55. Id.

56. Id at 949 .

57. Id.

58. Id. at 943 .

59. Id.

60. Id. at 944 .

61. Id. at 954. Judge Wilkey neglected to point out, lowever, that the defendants did not claim that they beheved that either the President or the Attorney General lad authorized the break-in. See notes 102-03 and accounpanying text infra. 


\section{B. Judge Merhige's Analysis}

Judge Merhige found Judge Wilkey's formulation of the defense of rehance on apparent authority of a government official to be too broad, but nevertheless also voted to reverse the convictions. He based his vote for reversal on a narrower exception to the mistake of law rule. Judge Merhige would allow a defense of mistake of law if, and only if, "an individual (1) reasonably, on the basis of an objective standard, (2) relies on a (3) conclusion or stateinent of law (4) issued by an official charged with interpretation, administration, and/or enforcement responsibilities im the relevant legal field." 62 Judge Merhige characterized the first three parts of the test as questions of fact, while part four is a question of law dealing with "interpretations of the paramenters of legal authority." 63

In support of his mistake of law defense, Judge Merhige asserted that it "would not serve to encourage public ignorance of law, for the defense requires that the individual either seek out or be cognizant of the official statement upon which lie or she relies. Soine knowledge of the law, verified by an independent and typically coinpetent source, is required."64 The judge would limit the use of the defense to inake it consistent with underlying policy by not extending it to reliance on government officials who have no interpretative or administrative responsibilities in the area involved in the mistaken opimion or decision. ${ }^{65}$

After formulating the test for the defense and stating the policy that supports it, Judge Merbige applied it to the facts of Barker. He concluded that the trial judge committed reversible error by not allowing the jury to decide whether Barker's and Martinez's asserted reliance on Hunt's authority and claimed belief in the lawfulness of their conduct fulfilled the requirements of a mistake of law defense.

IV

ThE "APPRopriate OfFicial" Limitation ON THE RELIANCE ON AN OFFICIAL INTERPRETATION OF THE LAW DEFENSE

Both Judge Wilkey and Judge Merhige based their decisions on the defense of reliance on an official interpretation of the law. Judge Wilkey used this defense as support for his adoption of a new defense of reliance on the apparent authority of a government official. Judge Merhige held that this defense apphied directly to the facts of Barker.

62. Id. at 955. This formulation is essentially the Model Penal Code's statement of the defense. See note 66 and accompanying text infra.

63. 546 F.2d at 955 .

64. Id.

65. Id. at 956. 
To evaluate the soundness of their analyses it is necessary to examine the scope of the reliance on an official interpretation of the law defense and the policies supporting its recognition.

\section{A. Analysis-Codes, Commentators, and Cases}

The Model Penal Code's formulation of the defense of rehance on an official interpretation of the law, section 2.04(3)(b)(iv), provides:

A belief that conduct does not legally constitute an offense is a defense to a prosecution for that offense based upon such conduct when: . . . (b) he acts in reasonable reliance upon an official statement of the law, afterward determined to be invalid or erroneous, contamed in . . . an official interpretation of the public officer or body charged by law with responsibility for the interpretation, administration or enforcement of the law defining the offense. ${ }^{66}$

Although the official comments accoinpanying section 2.04(3)(b)(iv) do not provide much guidance for interpreting the section, ${ }^{67}$ it is clear from the express language of this section that the defendant loping to cloak himself in this defense inay not rely on any government official. Rather, the defense is limited to those who rely on the appropriate government official-the "public officer or body charged by law with responsibility for the interpretation, administration or enforcement of the law defining the offense."

The commission reports ${ }^{68}$ and legislative bills ${ }^{69}$ proposed in the past seven years in an attempt to codify federal criminal law also contain sections that recognize the defense of reliance on an official interpretation of the law and are patterned after Model Penal Code section 2.04(3)(b)(iv). ${ }^{70}$ These versions of the reliance on an official interpreta-

66. MOdel Penal CODE $\$ 2.04$ (3)(b)(iv) (P.O.D. 1962).

67. Model Penal Code $\$ 2.04(3)$ (b)(iv), Comment at 138-39 (Tent. Draft No. 4, 1955).

68. National Commission on Reform of Federal Criminal laws, Final Report (1971).

69. S. 1437, 95th Cong., 1st Sess., 123 Cong. REc. 19025 (1977); S. 1, 94th Cong., 1st Sess., 121 Cong. Rec. 211 (1975); S. 1400, 93rd Cong., 1st Sess., 119 ConG. REc. 9655 (1973); S. 1, 93rd Cong., 1st Sess., 119 ConG. Rec. 92 (1973).

70. In 1966, Congress created a 12-member National Commission on reform of Federal Criminal Laws [hereinafter referred to as "the Brown Commission"] and gave it the responsibility of conducting a thorough review of the federal criminal justice systenn and unaking recommendations for revision and recodification of federal laws. Pub. L. No. 89-801, 80 Stat. 1516 (1960). Section 609 of the Brown Commission's fmal report, submitted to the President on January 7, 1971, provides, in pertinent part:

[A] person's good faith belief that conduct does not constitute a crime is an affirmative defense if he acted in reasonable reliance upon a statement of the law contained in: (d) an official interpretation of the public servant or body clarged by law with responsibility for the interpretation, administration or enforcement of the law defining the crime.

As in Model Penal Code $\S 2.04$ (3)(b)(iv), the express language of $\S 609$ demands that the official who is relied on be the appropriate official to be rendering the opmion or advice in question.

Following the submission of the Brown Commission's report, the Senate Criminal Laws Subcommittee held lengthy hearings during 1971 and 1972. These culminated in the introduction of 
tion of the law defense have contained added twists such as requiring that the interpretation be written ${ }^{71}$ and be contained in a "public" record or communication. ${ }^{72}$ All of these proposed sections, however, expressly limit the defense's applicability to an appropriate official. ${ }^{73}$

The case law on mistake of law supports the proposition that the rehance on an official interpretation of the law defense inay be invoked only when the official relied on is the appropriate official-the one authorized to render the particular advice or opmion later found to be

the first version of Senate Bill 1 on January 4, 1973. S.1, 93rd Cong., 1st Sess., 119 CoNG. REc. 92 (1973). Section 1-3C6(b)(2), "Ignorance or Mistake of Law," provided:

It is an affirmative defense that the defendant's conduct in fact conformed with an official statement of the law, afterward determined to be invalid or erroneous, contained in: (iii) an official, written interpretatiou issued by the head of a government agency, or his delegate, charged by law with responsibility for administration of the law defining the offense, if he acted in reasonable reliance on such statement of the law and in a good faith behef that his conduct did not constitute an offense.

Section 1-3C6(b)(2)(iii) makes it even clearer that not every official can be relied on, but only the head of an agency or his delegate.

At the same time the Brown Commisssion submitted its final report, President Nixon established a special criminal code revision unit within the Justice Department to study the report and to coordinate with congressional legislative activity. The Justice Department unit wrote a separate bill that was introduced as Senate Bill 1400 on March 27, 1973. S. 1400, 93rd Cong., 1st Sess., 119 CoNG. REC. 9655 (1973). Section 532 of S. 1400, "Official Misstatenent of Law," stated:

It is an affirmative defense to a prosecution under any federal statute that the defendant's conduct in fact conformed with an official statement of the law, afterward determined to be invalid or erroneous:

(b) which is contained in:

(3) an official, writteu interpretation issued by the head of a government agency, or his delegate, charged by law with responsibility for administration of the law defining the offense if the defendant acted in reasonable reliance on such statement of the law and with a good faith behef that his conduct did not constitute an offense.

Section 552 of S. 1, introduced in the 94 th Congress on January 15, 1975, provides, in pertinent part:

It is an affirmative defense to a prosecution under any federal statute that the defendant's conduct in fact conformed with an official statement of the law that was applicable to the conduct, that subsequent to the conduct was determined to be invalid or erroneous, and that was in fact:

(b) contained in a public record or a public communication constituting:

(3) an official, written interpretation issued by the head of a government agency, or his delegate, charged by law with responsibility for administration of the law to which the offense relates if the defendant acted in reasonable reliance on such statement and believed in good faith that his conduct did not constitute an offense.

S. 1, 94th Cong., 1st Sess. § 552, 121 CoNG. Rec. 211 (1975).

Senate Bill 1437, the most recent proposed draft of the federal criminal laws, does not contain a specific section outlining a defense for reliance on an official interpretation of the law. Section 501 of that bill provides in general that the defense of reliance on an official misstatement "shall be determined by the courts of the United States according to the primciples of the common law as they inay be interpreted in the light of reason and experience." $\$$. 1437, 95th Cong., 1st Sess. $\$ 501$, 123 CoNG. Rec. 19025 (1977).

71. S. 1, 94th Cong., 1st Sess. § 552, 121 CoNG. Rec. 211 (1975); S. 1400, 93rd Cong., 1st Sess. § 532(b)(3), 119 Cong. Rec. 9655 (1973); S. 1, 93rd Cong., 1st Sess. \& 1-3C6(b)(2)(iii), 119 Cong. Rec. 92 (1972). See note 70 supra for the pertinent text of these sections.

72. S. 1, 94th Cong., Ist Sess. \$ 552(b), 121 CoNG. REC. 211 (1975). See note 70 supra for the pertinent text of this section.

73. See note 70 supra. 
erroneous. Although the courts generally do not state that the "appropriateness" of the official controlled in deciding to allow the defense, most courts stress the position of authority of the given official and implicitly support the view that this position of authority is a crucial eleinent of the defense. ${ }^{74}$ One court articulated powerfully the policy behind allowing a reliance defense:

It would be unjust and monstrous to establish a tribunal . . . to decide questions that might arise . . . and, in case of an error by the tribunal to make a citizen answerable, criminally, and subject to prosecution. ${ }^{75}$ A couple of cases deny the defense expressly because the official involved was not the appropriate official to be relied on. In People $v$. Settles, ${ }^{76}$ the defendant was convicted of running a lottery in violation of the state penal code. In his defense, the defendant claimed that he had received a license from the City of Los Angeles to operate a gaine that the jury found to be unlawful. ${ }^{77}$ The court refused to recognize the defense because the city officials relied on by the defendant did not have the power to authorize his illegal conduct:

It appears to be contended also that some sort of estoppel arises from the act of the police commission in determining that the game in question was one of skill, and the further acts of other city officers in issumg a license for it. If the official action thus relied on had been that of soine officer directly charged with the duty of enforcing the law against lotteries and one of his duties had been that of issuing permits for games which in his opmion were not lotteries, we would have a

74. United States v. Pennsylvania Industrial Chemical Corporation, 411 U.S. 655, 674 (1973) ("The Corps [of Engineers] is the responsible administrative agency under the 1899 Act . . ."); Cox v. Louisiana, 379 U.S. 559, 571 (1965) ("[T]he highest police officials of the city, in the presence of the Sheriff and Mayor, in effect told the demonstrators that they could meet where they did . . . ."); Raley v. Ohio, 360 U.S. 423, 439 (1959) ("[A]t the inquiry [the Commissioners of the Ohio Un-American Activities Commission] were the voice of the State most presently speaking to the appellants."); United States v. Mancuso, 139 F.2d 90, 92 (3rd Cir. 1943) (rehance on a judge "acting within his jurisdiction," with "authority" to act); Texas Co. v. State, 31 Ariz. 485, 254 P. 1060 (1927) (defendant acted in reliance upon governor's veto of statute; veto later held unconstitutional); People v. Ferguson, 134 Cal. App. 41, 53, 24 P.2d 965, 970 (1933) (reliance on the appropriate administrator was in effect going to the "fountain head" of information on the subjcct); State v. Freeland, 318 Mo. 560, 567, 300 S.W. 675, 677 (1927) (defendant relied on game and fish commissioner, whose "judginent is paraniount" and who has "plenary authority and discretion as to the nueans to be used"; "the commissioner declared and exercised his judginent as he was einpowered to do"); State v. White, 237 Mo. 208, 211, 140 S.W. 896 (1911) (rehance on the "proper officers"); State v. Pearson, 97 N.C. 434, 436-37, 1 S.E. 914, $915-16$ (1887) (rehance on the officials charged with administering the laws at issue); State v. Davis, 63 Wis.2d 75, 82, 216 N.W.2d 31, 34 (1974) ("The possibility of an abuse of such a defense is effectively eliminatcd by limiting its application to the good faith reliance upon the legal opinion of a governmental officer whose statutorily created duties include the rendering of legal opinions as to actions of specific individuals or groups.").

75. State v. Pearson, 97 N.C. $434,436-37,1$ S.E. $914,915-16$ (1887).

76. 29 Cal. App. $2 d$ 781, 78 P.2d 274 (1938).

77. The license was issued under a Los Angeles City Ordmance which directed the police commission to determine whether a particular gane was a gane of skill, and if it was, to issue a permit for obtaining a license. 
[different case] . . . . The state has not confided to the police commission any authority in the enforcement of the lottery statute or any power to determine what is and what is not a violation thereof. The city cannot confer such jurisdiction, no matter how strongly it may attempt to do so, for this is not a municipal affair. ${ }^{78}$

There appears to be only one case holding that the official rehed on need not be the proper official to authorize the conduct later deeined to be illegal. In Reynolds $v$. State, ${ }^{79}$ the defendant was convicted for unlawfully carrying a pistol into a public dance liall. On appeal, the defendant claimed that the trial court erred in refusing to instruct the jury that "if he was acting with proper authority under the law and beheved that lie had a right to carry a pistol at the time and place charged, then he was entitled to an acquittal." 80 At the trial the defendant liad produced evidence slowing that on the afternoon of the dance a deputy marshal and night policennan of the city had requested him to go to the dance in order to keep the peace. The court of appeals reversed the conviction and held that defendant was entitled to an instruction that if he had held a good faith belief that he was acting with proper authority, he should have been acquitted.

The dissent argued vigorously against allowing the defense. According to the dissent, the only authority the defendant had to carry a pistol was based on the request by the deputy city marshal/night watchman. Under Texas law, however, neitlier a deputy city marshal nor the city nuarslial had a right to appoint a deputy. Because the defendant had not relied on the proper authority, the dissent concluded that he could not present a valid rehance defense:

I cannot agree to write into our law that any person carrying a pistol upon the request or at the suggestion of some one whom he inay believe had the right to tell him to carry such pistol, shall be, therefore, entitled to an acquittal, the ground upon which such right is asserted being the belief of the accused as to his such right. . . . It cannot be clainned that any law can be found authorizing a night policeman or deputy town marshal to authorize any other person to go to a dance or a rehgious meeting or other gathering armed with a pistol.

78. 29 Cal. App.2d at 785-86, 78 P.2d at 276. A similar result was achieved in United States v, Leathers, 26 F. Cas. 897 (D. Nev. 1879) (No. 15,581). In that case, the defendant was charged with residing as a trader in Indian country without a license. Although defendant's place of business was outside the lines of the reservation as demarcated by an Indian agent and a surveyor, he nevertheless was within the legal boundaries of the reservation. The court demied Leathers' defense based on his reliance on the Indian agent and surveyor, because they had no authority to establish boundaries:

The act of the Indian agent, or his subordinate, Fraser, in . . . fixing a boundary line of the reservation is . . . beyond the scope of the authority of either, and, of course, so far void and in no way binding the government, by estoppel in pais, or otherwise. Id. at 901 .

79. 132 Tex. Crim. 204, 104 S.W.2d 17 (1937).

80. Id at 205, 104 S.W.2d at 18. 
. . what becomes of the statutes which state specifically who may carry a pistol, if we hold that the law is that any man who claims to have been given the right by some justice, county commissioner, county or district judge, or member of an appellate court, or other person whom he respected and had confidence in, shall be entitled to have the jury told as the law that they inust acquit if they found the accused beheved he had the right to carry the pistol. ${ }^{81}$

The commentators also almost universally express the view that only the proper official may be rehed on in order for a defendant to propose the reliance defense. ${ }^{82}$ Language used by some commentators, however, can be read to support a broader defense. Throughout their discussion of the rehance on an official interpretation of the law defense, Hall and Seligman refer to officials who are authorized or who possess the power to imterpret the law as part of their official duties. ${ }^{83}$ At one poimt in their article, however, Hall and Sehgman advocate a more expansive defense, apphicable even if the official offering the legal interpretation was not the appropriate official to do so:

[We would] grant the defense in cases where there is express proof of rehance by the defendant on advice given him by state officials on matters within the ambit of their duties, even though these officials possess neither the power nor the authority to act in a rulemaking fashion. . . . [W]e must give the broader defense based upon reasonable appear-

81. Id. at 209-10, 104 S.W.2d at 19-20 (Lattimore, J., dissenting).

82. Hall, supra note 30 , at 24 ("law-declaring officials" with the "function to interpret law authoritatively"); Brett, supra note 30, at 203 ("pubhc officials whose duty it is to administer the law and who may therefore be expected to have made a careful study of its scope and effect"); $R$. Perkins, supra note 27, at 927 ("officers who are authorized to give such advice"); W. LAFAVE and A. ScoTr, supra note 27, at 368 (no defense for an individual seeking out just any public official).

Curiously, in support of this position, LaFave and Scott cite two cases: State v. Simmons, 143 N.C. 613, 56 S.E. 701 (1907) and Jones v. State, 25 S.W. 124 (1894). Neither of these cases, however, stands for the proposition that the defense is limited to the "appropriate" official. In Jones, the defendant was charged with having his saloon open on election day. The defendant claimed that an "officer" had informed him that it was legal to open the saloon after the election had closed. The court did not discuss the appropriateness of the official to render such an opinion or the duties and authority of the official, but merely based its decision to affirm the conviction on the general mistake of law rule: "Ignorance of a law cannot be pleaded in justification of its violation." 25 S.W. at 124. Steinberger v. State, 34 S.W. 617 (1896), supports the view that the Jones court did not reach its decision because the official involved was not the proper authority. In Steinberger, the defendant consulted and rehed on the proper authority-the election officials-as to the legality of opening a saloon on election day. Nevertheless, the court held this would be no defense.

Similarly, in Simmons the defendant game warden was charged with carrying a concealed weapon. In his defense, the defendant claimed that the court clerk had informed him at the time that he took his oath of office that because the defendant was a constable he had a right to carry a pistol and that he carried it in reliance on this opimion. The court did not discuss whether the court clerk was the appropriate authority to render such advice but merely affirmed the conviction on the ground that ignorance of the law is no excuse.

83. Hall \& Sehgman, supra note 28 , at $677-83$. 
ances. To do otherwise would force people to make difficult decisions as to the scope of authority of these officers, and would result in hesitation where unquestioning obedience is desired. ${ }^{84}$

Glanville Williams also employs ambiguous language in his discussion of the defense. ${ }^{85}$ Williams states the rule in terms of an "authorized state agency," over the matter."87 He then cites with approval the Model Penal Code and its reference to State $v$. White, ${ }^{88}$ a case involving a proper authority, an English case involving the "appropriate officer of the Admiralty," and a South African case involving the "proper officer." 89 Despite these contimuous references to the rule in terms of the appropriate official, Williams then quotes with approval from Lord Judge Denning a statement that he characterizes as "a wider primciple in line with the American authorities":

[W] henever government officers in their dealings with a subject take on themselves to assume authority in a matter with which the subject is concerned, he is entitled to rely on their having the authority which they assume..$^{90}$

Perhaps Williams is reading Lord Judge Denning's statement to refer only to appropriate officials, for it was written in a lower court decision involving an "appropriate officer of the Admiralty." On its face, however, it can be construed to apply to reasonable reliances on any government official.

Despite the ambiguous language in soine commentary, and the Reynolds case $^{91}$ notwithstanding, the weight of authority holds that a defendant mnst rely on only the appropriate official possessing the power to authorize the conduct later found to be illegal. Although denial of the defense in instances of reliance on officials who reasonably appear to possess the required authority may have harsh results, significant policy considerations mandate that the mistake of law defense not be apphied unless the official relied on is the appropriate official.

\section{B. The Policy Basis for the Appropriate Official Limitation}

The policy basis for restricting the mistake defense to reliance on only the appropriate officials is found in the two critical distinctions between appropriate officials and other government officers. First, ap-

84. Id at 675. Hall \& Seligman would have allowed a mistake of law defense in Settles, supra note 76 and accompanying text. Id. at 681-82.

85. G. WiLliaMs, supra note $27, \S 106$, at $302-03$.

86. Id, at 303.

87. Id. at 302 .

88. 237 Mo. 208, 140 S.W. 896 (1911).

89. G. WILliaMs, supra note 27, § 106, at 303.

90. Id.

91. See notes 79-81 supra and accompanying text. 
propriate officials, because it is their duty to administer, enforce, or interpret the law in question, are inore likely than other officials to have made a careful study of the law's scope and effect. Second, appropriate officials, unlike other officers, are in positions of accountability and responsibility, thus significantly decreasing the opportunity for abuse of power. ${ }^{92}$

Ironically, it is Judge Wilkey himself in United States $v$. Ehrlichman, ${ }^{93}$ a coinpanion case to Barker, who offers a compelling policy argument on why allowing reliance on an official other than the proper official might have dangerous ramifications, especially in the area of fourth aniendment searches and seizures:

The danger of leaving delicate decisions of propriety and probable cause to those actually assigned to ferret out "national security" information is patent, and is indeed illustrated by the intrusion undertaken in this case, without any nore specific Presidential direction than that ascribed to Henry II vexed with Becket. As a constitutional inatter, if Presidential approval is to replace judicial approval for foreign intelligence gathering, the personal authorization of the President-or his alter ego for these matters, the Attorney General-is necessary to fix accountability and centralize responsibility for insuring the least intrusive surveillance necessary and preventing zealous officials from misusing the President's prerogative.

92. Judge Leventhal states the rationale for limiting the defense to reliance on appropriate officials in the following terms:

The Model Penal Code hedges in the defense to permit reliance only on an "official interpretation of the public officer . . . charged by law with responsibility for the interpretation, administration or enforcement of the law defining the offense." (emphasis added). . . . These restrictions on the applicability of the official statement exception did not arise haphazardly; they were deliberately drafted to allow, and indeed to promote, good faith reliance on official pronouncements with objective indicia of reliability-those made by officials specifically charged with interpreting or enforcing the specific law defining the specific offense charged against the defendant. A defense so confimed has values for the law: It avoids punishing those who rely on a crystallized position taken by the officer or body charged by statute with interpreting the law in a particular area. The officer's position in a channel of authority is readily identifiable; any mistakes lie inakes can be remedied, by readily perceived and structured avenues of rehief. There is no opening the door to justification for serious offenses based on unrecorded discourse from someone who has an undefmed but high-sounding berth in the government.

The "official interpretation" defense thns structured is a functional analogue of the defenses of reliance on a statute, judicial decision or administrative order. It is justified by its twin underlying assumptions that the official is one to whom authority has been delegated to make pronouncements in a field of law, and that the authority can be held accountable by explicitly grounding it in the hands of an identifiable public official or agency. So grounded, the imterest of both private citizens and government is served by protecting actions taken in reliance on that imterpretative authority. . . . The official misstateinent of law defense embodies a fundamental requirement that the erroneous interpretation be made by an official in fact possessing the power to nake a binding interpretation; ....

546 F.2d at 968-69 (Leventhal, J., dissenting).

93. 546 F.2d 910 (D.C. Cir. 1976), cert. denied, 429 U.S. 1120 (1977). 
... Even though the employees and administrators of the regular agencies might have the background, training, and departmental discipline to make responsible, expert decisions, the risk of their myopic abuse of such powerful prerogative is smiply too great to permit its delegation. That risk is substantially magnified when the decision-making group, as here, is an amorphous, ad hoc unit with no tradition of public service and no clear lines of responsibility. ${ }^{94}$

By extending the mistake of law defense in Barker to include reasonable reliance on the apparent authority of any government official, Judge Wilkey increased the chances for success of illegal projects initiated by minor government officials who need the assistance of "footsoldiers" to bring these projects to fruition. Under Judge Wilkey's view of the law, any low-echelon government agent in a position with "official trappings," such as E. Howard Hunt, ${ }^{95}$ may recruit bands of adventurers who are not particularly worried about authorization, ${ }^{96}$ but are content to do his bidding and to work on a "need-to-know" basis, that is, needing-to-know nothing about authorization. Admittedly, the defense would not be allowed unless the mistake as to the official's authority was "reasonable," but as Hunt has already so ably demonstrated, it is quite easy to couch activities in vague constitutional or national security terms to produce apparent legality.

Even if a jury could find that Barker and Martinez reasonably believed that Hunt had authority to authorize the burglary, the rehance on an official interpretation of the law defense is inapplicable liere for all the reasons Judge Wilkey offered in the Ehrlichman case. The defense inust be restricted to reliance on the appropriate official who is both in a position of accountability and responsibility and nost likely to know the scope and effect of the law in question. Ouly then will citizens be encouraged to seek out this official and unscrupulous officers be discouraged froin organizing illegal activities.

\section{Application of the Appropriate Official Limitation to Barker}

Judge Wilkey supported his recognition of defendants' defense of reliance on apparent authority by implicitly concluding that reliance on Hunt's apparent autliority was sufficiently analogous to a police of-

94. Id. at 926-27.

95. Hunt wrote Barker on White House stationery, gave Barker an unlisted White House number at which he could be reached, and once inet with Barker in the Executive Office Building. 546 F.2d at 943 (Wilkey, J.). Hunt had also been one of Barker's immediate superiors during the Bay of Pigs invasion. Id.

96. When the defendants inet with Hunt and Liddy the day before the break-in to finalize the plans, there was no discussion of authorization. Defendants offered no evidence that Ehrhichman or the Attorney General had expressed or imphed the operation was legal. Barker and Martinez did not seek outside advice concerning the factual requirenents necessary for the operation, and they never claimed that they beheved they were acting under a warrant. Id. at 959,962 (Leventhal, J., dissenting). 
ficer's reliance on a judicial warrant-an example of the reliance on an official interpretation of the law defense-to justify a similar result in each situation. Judge Wilkey failed, however, to identify a crucial distinction between the conduct of a police officer who relies on an invahd judicial warrant and the actions of the defendants in Barker: rehance on an appropriate official. A judge issuing a warrant is the appropriate government official einpowered by law to authorize the pohce officer's conduct. Hunt, in contrast, was not the appropriate official charged by law to authorize the break-in. This distinction critically flaws Judge Wilkey's analogy and consequently weakens its supportive force.

Usually, absent exigent circumstances not present in Barker, only a judge has the power to authorize a search by issuing a warrant based on a showing of probable cause. ${ }^{97}$ Thus, under normal circuunstances, since Barker and Martinez did not claim that they beheved that a judicial warrant authorizing the break-in had been issued and did not believe that a judge had condoned their activity, ${ }^{98}$ they could not assert rehance on the appropriate government official. The Ellsberg break-in, however, was couehed in terms of "national security," and there exists a body of law ${ }^{99}$ supported by opimions of the Attoruey General and the Justice Departınent ${ }^{100}$ that fraines a constitutionally conferred Presi-

97. See generally Katz v. United Staes, 389 U.S. 347, 354-59 (1967).

98. The defendants did not assert during the trial that they believed that a warrant lad been issued. 546 F.2d at 960 n.7, 962 (Leventhal, J., dissenting). On appeal, lowever, defendants raised this claim, but all three judges apparently considered this to be merely a self-serving assertion, and all chose to ignore it.

99. United States v. Ehrlichman, 546 F.2d 910 (D.C. Cir. 1976) (dictum), cert. denied, 429 U.S. 1120 (1977); Zweibon v. Mitchell, 516 F.2d 594 (D.C. Cir. 1975) (en banc), cert. denied, 425 U.S. 944 (1976); United States v. Butenko, 494 F.2d 593 (3d Cir. 1974) (en banc), cert. denied sub nom. Ivanov v. United States, 419 U.S. 881 (1974); United States v. Brown, 484 F.2d 418 (5th Cir. 1973), cert. denied, 415 U.S. 960 (1974); United States v. Kearney, 426 F. Supp. 1108, 1112-14 (S.D.N.Y. 1977). In United States v. United States District Court (Keith), 407 U.S. 297 (1972), the Supreme Court held that a warrant is required for electromic surveillance in domestic security imvestigations and reserved for decision all questions concerning the procedure required to be used to gather foriegn imtelligence. But see Katz v. United States, 389 U.S. 347, 359-60 (1967) (Douglas, J., and Brennan, J., concurring); United States v. Ehrhichman, 546 F.2d at 933-40 (Leventhal, J., and Merhige, J., concurring); Note, Foreign Sccurity Surveillance and the Fourth Amendment, 87 HARv. L. Rev. 976 (1974); Comment, Privacy and Poilitical Freedom: Application of the Fourth Amendment to "National Security" Investigations, 17 U.C.L.A. L. REv. 1205 (1970).

On April 20, 1978, the Senate passed by a 95-1 vote, and sent to the House, S. 1566, the Foreign Intelligence Surveillance Act of 1978. This bill rejects the executive brancl claims of "inherent power" to wiretap in the foreign intelligence field and requires government agents to follow a detailed apphication and authorization procedure culminating in a judicial warrant before they engage in foreign intelligence electronic surveillance. S. 1566, 95th Cong., 2d Sess., 124 CONG. REC. S5994-6019 (daily ed. April 20, 1978).

100. In Umited States v. Ehrlichman, 546 F.2d 910, the Justice Department filed a two-page memorandum for the United States as amicus curiae that asserted that a warantless search is lawful under the fourth amendment when there is "sohd reason to believe that foreign espionage or intelligence is imvolved," imtrusion is "kept to the minimum," and there is "personal authorization by the President or the Attorney General." Final Report of the Select Committee to StUdy GOVERNMENTAL OPERATIONS WITH RESPECT to INTELligence ACTIVITIES, S. Rep. No. 
dential power in national security inatters to authorize the visual or auditory search of inaterial without a judicial warrant. ${ }^{101}$ Yet Barker

94-755, 94th Cong., 2d Sess. Book III at 369 (1970). See also Report of THE DEPARTMENT of Justice Concerning Its Investigation and Prosecutorial Decisions with Respect to Central Intelligence Agency MaIl Opening Activities in the UNited States 36-39 (January 14, 1977) [hereinafter referred to as Department of Justice Report].

101. The weight of authority indicates that only the President or the Attorney General has the power to authorize warrantless searches under the aegis of "national security." Presidential inemoranda froin 1940 to 1965 setting forth executive policy regarding electronic surveillance in national security matters lave stressed the requirement of personal approval by the President or the Attorney General. See, e.g., Appendix to dissenting opinion of Judge MacKinnon, United States v. Barker, 514 F.2d 208, 246-48 (D.C. Cir. 1975) (en banc), cert. denied, 421 U.S. 1013 (1975). In his concurring opinion in Katz v. United States, 389 U.S. 347, 364 (1967), Justice White indicated the possibility of an "executive warrant," but only if "the President of the United States or his chief legal officer, the Attorney General, has considered the requireinents of national security and authorized electronic surveillance as reasonable." In a two-page meinorandum for the United States as amicus curiae in United States v. Ehrlichman, 546 F.2d at 935, the Justice Department asserted that an executive warrant exists where there is " "personal authorization by the President or the Attorney General.' "In Ehrlichman Judge Wilkey expressly affirmed the lower court's ruling that the "national security" exemption can only be invoked "if there has been a specific authorization by the President, or by the Attorney General as his chief legal advisor, for the particular case." Judge Wilkey explained the policy justifying limiting the power to authorize warrantless searches in "national security" matters as follows:

No court, Justice of the Suprenee Court, or Presidential administration has ever suggested a power which could be generally delegated, for example, even to regular intelligence agencies, like the FBI and CIA, let alone to the extra-statutory group involved in the instant case. Even though the employees and administrators of the regular agencies might have the background, training, and departmental discipline to nake responsible, expert decisions, the risk of their myopic abuse of such a powerful prerogative is simply too great to permit its delegation. That risk is substantially magnified when the decisionmaking group, as here, is an amorphous, ad hoc, umit with no tradition of public service and no clear lines of responsibility.

....

As a constitutional matter, if and to the extent that Presidential approval inay replace judicial approval for foreign intelligence gathering, the personal authorization of the President-or of his Cabinet alter ego for these nuatters, the Attorney General-is necessary to fix accountability and centralize responsibility for insuring the least intrusive surveillance necessary and preventing zealous officials fron misusing the Presidential prerogative.

Id. at 927-28.

Judge Duffy recently stated that a warrantless search pursuant to the "national security" exception to the fourth amendment's warrant requirement could be conducted only "with the express authorization of the President or Attorney General" because "any less of a requirement would give any minor yet zealous official a free hand to disregard the vital privacy interests which he at the core of Fourth Amendment protection sinuply by conjuring up the 'national security' and 'foreign influence' spectre." United States v. Kearney, 436 F. Supp. 1108, 1113 (S.D.N.Y. 1977).

A recent Justice Department Report, however, indicates that the President inay delegate the power to approve "national security" searches to Executive Branch officials other than the Attorney General:

[T] he Department [of Justice] beheves that the evolving law in this area requires such authorization to be express. The executive official to whon the power to approve such surveillance has bcen delegated inust take steps to assure himself that the surveillance is reasonable under Fourth Amendment standards. . . . In urging the courts to accept exccutive authorization of surveillance, the Department has argued that in each instance the personal approval of the President or his delegate, such as the Attorney General, would be eniployed to ensure the degree of consideration and control necessary under the Fourth Amendment.

Department of Justice Report, note 100 supra, at 36-37. Judge J. Skelly Wright, in his opinion in 
and Martinez did not claim that they believed that the President ${ }^{102}$ or the Attorney General ${ }^{103}$ lod autliorized the break-in by executive warrant. Nor did they claim a belief that Ehrlichman had authorized the Ellsberg operation. ${ }^{104}$

Although Barker and Martinez apparently did not believe that the President, the Attorney General or John Ehrlichman had authorized the break-in, Judge Wilkey nevertheless concluded that "Barker's and Martinez's belief was that there was autlorization within the White House."105 According to Judge Wilkey, Barker and Martinez believed that their "actions were duly authorized by an organization 'at the White House level . . . above the FBI and the CIA." "106 It is unclear just what this nebulous authority was. Judge Wilkey seemed to realize this contradiction when he stated that "[Barker's and Martinez's] justification is a reasonable mistake of law, and in their position and known facts a reasonable mistake of law involves a mistake as to Hunt's authority, not that of the Attorney General or President."107 Judge Wilkey's clraracterization of Barker's and Martinez's reliance in Barker-Watergate is equally applicable to Barker-Ellsberg, although le struggles to avoid admitting it:

Their willingness to enlist in the operation and help carry it out derived primarily froin their staunch faith in one man, E. Howard Hunt. . . . It did not occur to thein to second-guess Hunt's decisions, let alone question his authority. ${ }^{108}$

Thus, despite Judge Wilkey's attempt to characterize the facts of the case to bring Barker and Martinez under the aegis of reliance upon an executive warrant, the facts in the record are just not so. Rather, Barker

Zweibon v. Mitchell, 516 F.2d at 614 n.43, questions why the Attorney General, rather than the Secretary of State, should be the Executive official delegated to authorize "national security" searches "in light of the fact that the asserted complexity and specialized nature of foreign pohicy matters is advanced as a factor militating against prior judicial oversight of foreign security surveillance...."

If in fact the President has expressly delegated the power to approve "national security" searches to an Executive Branch official other than the Attorney General, a good faith, reasonable rehance on such official that a search is legal should be exculpatory. For the reasons expressed by Judges Wilkey and Duffy, however, this defense should be limited to authorization by cabinetlevel officials.

102. 546 F.2d at 949 n.31 (Wilkey, J.); Id. at 962 (Leventhal, J., dissenting).

103. Id. at 962 (Leventhal, J., dissenting).

104. Id. In United States v. Ehrlichman, 546 F.2d 910, the jury found that Ehrliehman liad indeed authorized the break-in. Even if Barker and Martinez had believed that Ehrliehman had authorized the break-in, however, this behef could not be the basis of a rehance on an offieial interpretation of the law defense because Ehrlichman was not the appropriate government official to authorize such conduct. See note 101 supra.

105. 546 F.2d at 951.

106. Id.

107. Id. at $949-50 \mathrm{n} .31$ (emphasis added).

108. United States v. Barker, 514 F.2d 208, 248 (D.C. Cir. 1S 15) (en banc) (Wilkey, J., disscnting), cert. denied, 421 U.S. 1013 (1975). 
and Martinez relied on only one person, E. Howard Hunt, an official who clearly did not possess the power to authorize the illegal activity involved in this case. ${ }^{109}$

Judge Merhige correctly adopted the appropriate official limitation as part of the mistake of law defense. He required the statement relied on to be inade by "an official charged with interpretation, administration, and/or enforcement responsibilities in the relevant legal field." ${ }^{110}$ Indeed, Judge Merhige expressly stated that the policy underlying the defense "is limited by the actual existence of an appropriate official"111 and "the defense does not extend to reliance on individuals, who although employed in a public capacity, have no interpretative or administrative responsibilities in the area associated with the legal concepts involved in the mistaken opinion or decision."112 Under Judge Merhige's analysis, the official relied on must be the appropriate official. E. Howard Hunt clearly is not the appropriate, responsible government official under the judge's analysis, ${ }^{113}$ and he acknowledges this by basing his decision on a "conduit theory." Under the conduit theory Hunt inerely played the role of a go-between separating the appropriate authority and Barker and Martinez. Judge Merhige phrased the relationship in this way:

Barker and Martinez assert that they relied on Hunt's authority as delegated from an intelligence superstructure controlled by the White House, and firmly believed that they were acting in a legal capacity. . . . A jury may well find that John Ehrlichman, then Assistant to the President for Doinestic Affairs, expressed or implied that the breakin of Dr. Fielding's office was legal under a national security rationale, and that Hunt, as an executive official in a go-between capacity, passed the position on to the defendants, which they, acting as reasonable inen, rehed upon in performing the break-in. ${ }^{114}$

Judge Merhige's conduit analysis is theoretically plausible, but is not applicable to the facts of Barker. As long as the defendant correctly

109. Hunt had only an ad hoc, undefined position in the White House. He had no online enforcement or interpretative powers or responsibilities. His undifferentiated power stemmed solely froin ineinbership in a large White House bureaucracy. . . .

.. . Certainly Hunt cannot sensibly be described as having been charged by law with responsibility for interpreting or enforcing either $\$ 241$, or the Constitution from which the violations of $\$ 241 \mathrm{~m}$ this case sprang. Nor can it be said in any meaningful sense that he had the power to provide an official imterpretation of the law. ...

... A staff man or even a lower echelon official of the White House may be taken as a inan of presumptive standing and even influence, but not seriously as a source of official interpretation of law, inuch less of such matters as the validity of a stealthy breaking and entering.

546 F.2d at 968-69 (Leventhal, J., dissenting) (citations omitted).

110. 546 F.2d at 955 .

111. Id. at 956 .

112. Id.

113. See Judge Leventhal's description of Hunt's position in note 109 supra.

114. 546 F.2d at 957. 
identified as his source of authorization the appropriate official vested by law with the power to authorize and to approve the conduct in question, there is no reason why the official authorization cannot be conveyed to the defendant through conduits. ${ }^{115}$ The defendant must, lowever, believe in good faith that the appropriate official properly exercised the power and legally delegated the authority, thereby inaking the conduct lawful. This theory has no application to the facts of Barker. Barker and Martinez did not claim to have beheved that the President, the Attorney General, or John Ehrlichman had authorized the Ellsberg break-in. Even if the defendants did believe that Ehrlichman had approved the operation, he was not the proper official to do so. ${ }^{116}$ In addition, references to authority conferred by "an intelligence superstructure controlled by the White House" are too vague to constitute reliance on an appropriate official.

115. A recent law review article questions the desirability of allowing defendants to rely on an individual acting as an intermediary or conduit of the appropriate official:

[I] is questionable whether persons who are informed of interpretations through an intermediary such as Hunt should be entitled to rely on such second-hand information. The official interpretation exception seeks to immunize the conduct of those individuals who demonstrate, through their efforts to learn the law, a law-abiding nature. Extending this exception to individuals who learn of interpretations second-hand would benefit those who do not take the desired initiative. In addition, allowing an intermediary to "pass on" an interpretation, rather than requiring that it be obtained directly from the interpreter, raises possibilities that the intermediary will fabricate an interpretation and will thereby provide a defense to recipients of his communication who engage in undesirable conduct. Conversely, the third party who receives the information through an intermediary inight prefer to take it at its face value, without attempting to verify the interpretation with its supposed source, if he knows that it will provide a defense in the event the conduct turns out to be illegal.

Comment, Reliance on Apparent Authority as a Defense to Criminal Prosecution, 77 Colum. L. REV. 775, 800 n.121 (1977).

It is certainly preferable to require that individuals be personally informed of the interpretation of the law or authorization by the appropriate government official. This is not always practical, however. For example, it is not feasible for government agents im the field to personally talk to the President or Attorney General with regard to authorization for a "national security" search. Although allowing defendants to rely on an intermediary to pass on the official interpretation or authorization does indeed create the possibility that the intermediary will falsify authorizations, the inere possibility of this occurring does not justify denying the defense to an individual who in good faith believes that the official statement came from the appropriate official.

It is interesting to note that the author of the above-cited law review article recognizes that the representations of an intermediary who conveys an official statcment from the appropriate official may sometimes be sufficient to allow the defense:

Production of a paper that appears to be a warrant inight suffice. Similarly, a representation that "the President lias approved this" inight not suffice in general, but inight well be sufficient where, as in the Barker cases, other circumstances-e.g., Hunt's clear White House connections-gave the actor a basis to believe that such a representation was probably true.

77 Colum. L. REv. at 792 n.88.

For a discussion of proposed legislation to restrict the use of delegated authority, see note 99 supra.

116. The President did not authorize Ehrlichman to approve warrantless searches in "national security" unatters. Umited States v. Ehrlichman, 546 F.2d at 927-28. See note 101 supra for a discussion of the delegation of the President's power to authorize "national security" searches to Executive Branch officials. 
Thus, it seems that Judge Merhige, although adopting a correct analytical framework, nevertheless fell into the trap of trying to squeeze the facts on the record into that legal framework.

If Barker and Martinez had believed in good faith that the President himself, the appropriate official in the context of this case, ${ }^{117}$ had authorized the Ellsberg burglary ${ }^{118}$ and they reasonably believed that such conduct was lawful, the defense of reliance on an official interpretation of the law would be a proper defense. On these supposed facts the defendants would be relying on the appropriate government official charged by law to approve their conduct. It would be extremely unfair to require private citizens sucl as Barker and Martinez to have a greater understanding than the proper government official, so their reasonable reliance should protect them froin criminal sanctions attached to the approved but unlawful conduct. ${ }^{119}$

117. See note 101 supra for a discussion regarding the delegation of the President's power to authorize "national security" searches.

118. Presidcnt Nixon has denied that he had prior knowledge of the break-in and that he therefore could not and did not authorize it. According to Judge Gesell, "the available transcripts of the confidential tape recordings support that claim." United States v. Ehrlichman, 376 F. Supp. 29, 34 (D.D.C. 1974), affd, 546 F.2d 910 (D.C. Cir. 1976), cert. denied, 429 U.S. 1120 (1977). In a recent interview with Britislı television personality David Frost, Nixon stated that if Ehrlichman had advised him of the intended Ellsberg break-in, "I would lrave said, "Go right ahead." N.Y. Times, May 19, 1977, § A, at 21, col. 1 .

119. In his dissenting opinion, Judge Leventhal expressed "puzzlentent," "wonder," and "despair" at the nuajority's decision to allow a mistake of law defense wlere the conduct sought to be excused was a burglary. 546 F.2d at 958 . Similarly, in United States v. Ehrlichman, 376 F. Supp. at 35, Judge Gesell stated that "it is well established that a mistake of law is no defense in a conspiracy case to the knowing performance of acts whicl, like the unauthorized entry and search at issue here, are malum in se." The court of appeals' decision to allow a mistake of law defense in counection with the defendants' activity is, however, consistent with the logic and policies underlying the geueral doctrine and its exceptious.

Each of the cases cited by Judge Gesell in support of his general proposition, id., can be distinguished from the instant case: the defendants in the cited cases asserted a general defense of mistake of law rather than one based on an exception to the general rule. Admittedly most cases involving reliance on an official stateinent of the law involve the interpretation of codes or regulations and refer to activities which are generally designated mala prohibita. The language of MOdel PENAL CODE § 2.04(3)(b) and the Commeuts accompanying that section, MODEL PENAL CODE § 2.04(3)(b)(iv), Comment at 138-39 (Tent. Draft No. 4, 1955), lowever, do not restrict its application to conduct which is referrcd to as malum prohibitum, and an examination of the policies justifying the recognition of this defense indicate that it slould be recognized with regard to conduct cliaracterized as malum in se.

The purpose of the reliance on an official interpretation of the law defense is to promote good faith reliance on announcements made by the public official "charged by the law with the responsibility for the interpretation, administration or enforceinent of the law defining the offense." Implicit in this defense is the recognition that it would be unreasonable to require a private citizen to liave a greater understanding of the law than the appropriate government official. Both of these considerations apply wlien the activity sought to be excused is malum in se.

Although Judge Gesell recognized the existence of the reliance on an official interpretation of the law defense, lie nevertheless stated that it could not be "stretched to encompass a mistake based upon the assurances of an alleged co-conspirator with regard to the criminality of acts that are malum in se." 376 F. Supp. at 35 . Judge Gesell's blanket statement puts an unfair burden on the private citizen who relies on an appropriate official's interpretation of the law. If the President 
Since Barker and Martinez did not believe in good faith that the President had authorized their conduct, the defense of reliance on an official interpretation of the law slould fail. Imposing criminal liability on defendants wlio reasonably believed in good faitli that their conduct was lawful is admittedly a liarsli result. Judge Leventhal wisely reminds us, however, that Barker's and Martinez's "mistake of law, whether or not it is classified as reasonable, does not negative legal responsibility, but at best provides a reason for clennency on the ground that the strict rules of law bind too tight for the overall public good."120 Mechanisms in the system, such as prosecutorial discretion, ${ }^{121}$ jury nullification, judicial sentencing, and executive clemency, serve to mitigate the sometimes harsli results of a strict application of the law. Indeed, one of these mechanisms actually came into play in Barker. The trial judge sentenced Barker and Martinez to only three years probation. ${ }^{122}$ Judges who, in future cases, are presented with facts that do not warrant a mistake of law defense should follow Judge Leventhal's advice and let these inediating devices alleviate the harsh consequences of correctly applying the mistake of law rule and its limited exceptions. ${ }^{123}$ This approacli should be preferred to either an expansion of the boundaries of the exceptions to the mistake of law rule or a distortion of the facts of the case to fit one of the recognized exceptions to the mistake of law rule.

\section{$\mathrm{V}$}

\section{IMPLICATIONS OF BARKER FOR PUBLIC EMPLOYEES}

Barker considered the reliance on an official interpretation of the law defense as applied to private individuals actimg on the advice of a government official. But the most significant ramification of Barker may be the possibility that government employees charged witl a crime inay claim reasonable, good faith reliance on a government official's authorization of conduct later found to be unlawful. ${ }^{124}$ Two govern-

himself had personally authorized the defendants to conduct the Ellsberg break-in, and they reasonably relied on his interpretation of the law with regard to the legality of this conduct, allowing thein to invoke a mistake of law defense would be consistent with the policy considerations supporting the general rule. It would be grossly unfair to deny them a mistake of law defense in such a case.

120. 546 F.2d at 972.

121. Attorney General Bell recently exercised prosecutorial discretion and dropped charges against indicted FBI agent John Kearney. S.F. Chronicle, April 11, 1978, at 1, col. 6.

122. 546 F.2d at 972.

123. Id. See also United States v. Barker, 514 F.2d 208, 236 (D.C. Cir. 1975) (en banc) (Bazelon, C.J., concurring), cert. denied, 421 U.S. 1013 (1975); United States v. Leathers, 26 F. Cas. 897, 901 (D. Nev. 1879) (No. 15,581).

124. See, e.g., United States v. Kearney, 436 F. Supp. 1108, 1116 (S.D.N.Y. 1977): "That Kearney was an FBI agent himself, and not simply a 'meunber of the public,' does not preclude him from relying on the opimion, if any, of these officials as to the relevant law." See also Depart- 
ment agents already have atteinpted to invoke this defense.

In United States $v$. Kelly, ${ }^{125}$ a former customs official ${ }^{126}$ appealed convictions for conspiracy and electronic eavesdropping. The defendant cited Barker and claimed that he believed in good faith that his actions were lawful because his superiors had approved the bugging in advance. The court in Kelly found the defense inapplicable because the defendant neither proposed a legal theory that would support a reasonable belief that his superiors had the authority to approve the operation, ${ }^{127}$ nor in good faith beheved his superiors had such authority. ${ }^{128}$

The second case involved former FBI supervisor, John Kearney, who was indicted ${ }^{129}$ in April, 1977, for his participation in mail openings and wiretaps between 1970 and 1972 agamst persons thought to be associated with Weather Underground fugitives. During pretrial motions, Kearney indicated that he would present at trial a mistake of law defense. ${ }^{130}$

Kearney's indictment recently was dismissed at the same time former Actimg Director L. Patrick Gray and two other former high FBI officials were indicted for ordermg break-ims, wiretaps and mail openings. ${ }^{131}$ Nevertheless, the charges against Kearney provide a fruitful setting in which to analyze the rehance on an official interpretation of the law defense.

It is not clear precisely what authorization existed for the operations in which Kearney allegedly participated. ${ }^{132}$ It does appear, however, that neither the President nor the Attorney General authorized

ment of Justice Report, note 100 supra, at 42-43. A minor government official, because of his position, should have a more difficult time than a private citizen in proving that his reliance was reasonable. $I d$.

125. 556 F.2d 257 (5th Cir. 1977).

126. The Customs Service is a brancli of the Treasury Department.

127. 556 F.2d at 266 n.7.

128. Id. at 266-67.

129. N.Y. Times, April 8, 1977, § A, at 1, col. 2.

130. United States v. Kearney, 436 F. Supp. at 1114-17.

131. S.F. Chronicle, April 11, 1978, at 1, col. 6. Attorney General Bell dropped the charges against Kearney as an exercise of his prosecutorial discretion and not because Kearney's conduct was legally justified: " All charges against Kearney in New York were dismissed in keeping with iny exercise of prosecutorial responsibility. He was in my judgment carrying out orders. That is not an excuse and it is not to be so construed in the future, ...." Id. at 20, cols. $3-4$.

Indeed, at the same time Attorney General Bell dropped the charges against Kearney lie stated that disciplinary action would be taken against seventy other FBI agents and Justice Department officials for their roles in illegal black-bag operations. Id. at 1, col. 6. Former FBI Acting Director L. Patrick Gray, Associate Director Mark Felt, and Chief of Intelligence Edward S. Miller were recently indicted for their roles in ordering these operations. Id. at 1, col. 6 .

132. For a general discussion of FBI policy and practice regarding authorization for breakins, microphone installations and inail openings, see FINAL. REPORT OF THE SELEct CoMmtteE TO STUDY GOVERNMENTAL OPERATIONS WITH RESPECT To INTElligence ACTIVITIES, S. Rep. No. 94755, 94th Cong., 2d Sess. Book II at 190-92, Book III at 303-05, 355-71 (1976); see also L.A. Times, Aug. 27, 1976, § 1, at 20, col. 1; L.A. Times, July 29, 1976, § 1, at 1, col. 1. 
the warrantless wiretaps and mail openings. ${ }^{133}$ Nevertheless, if Kearney could have satisfied the elements of the reliance on an official interpretation of the law defense - that he believed in good faith that the President or the Attorney General ${ }^{134}$ lad authorized the operations, and that he reasonably believed such operations were lawful-such a showing slould be exculpatory. On the other liand, if Kearney thought that approval had coine ouly from Bureau superiors who did not have the power to authorize the operations ${ }^{135}$ - even if he believed these superiors lad sucl power-this would not excuse. ${ }^{136}$

Recognition of the reliance on an official interpretation of the law defense for government officials and private citizens may initially seem to be the same as the Nureinberg defense of "I was just following orders."137 Unlike the Nuremberg claims, however, the reliance on an official interpretation of the law defense is ouly applicable where the accused relied in good faith on the appropriate government official and reasonably believed that the conduct in question was lawful. ${ }^{138}$ "Black

133. United States v. Kearney, 436 F. Supp. at 1114: "The government has represented that no such authorization exists in this case . . . [A]nd defendant does not seem to press the fact of existeuce [of Executive authorization]."

134. See notes 99-101 supra.

135. See note 101 supra.

136. In response to defendant Kearney's discovery inotions, the Government argued that the reliance on an official interpretation of the law defense was mapplicable because

there is no legal theory under which defendant's superior and F.B.I. headquarters personnel eould liave validly authorized the warrantless surveillance, there exists no legal authority in these officials upon whom defendant purports to have rehed, and that, in any event, these superiors are not appropriate official sources upon whose opinion defendant may have reasonably relied.

436 F. Supp. at 1115-16. Judge Duffy disagreed with these government contentions: "[1]t is not whether these supervisors actually possessed the authority to authorize the surveillance in issue that is relevant . . . but rather whether these persons were officials 'charged with interpretation, administration, and/or enforcement responsibilities' with respect to the relevant law so that any conclusion or 'statement' thereof could have been reasonably relicd on by Kearney." Id. at 1116 n.4. According to Judge Duffy, these FBI superiors are officials who are charged with enforcement responsibilities:

The F.B.I. has been designated by Presidential directives to take charge of investigations relating to subversive activities and the like, and the Bureau director is responsible for carrying out this responsibility. See 28 C.F.R. $§ 0.85$ (1976). It is thus an agency charged with enforcement responsibility in counection with the relevant law in issue, and its director and his immediate subordinates arguably are officials in whom reliance inay properly be placed.

Id. at 1116.

Judge Duffy lias inaccurately characterized the "relevant law in issue" as "imvestigations relating to subversive activities." Id. The FBI clearly has enforcement responsibilities in this broad area. The real law im issue in Keamey, however, is a narrow question of imterpretation with regard to the applicability and scope of the Executive warrant-whether the officials whoin Kearney believed had authorized his conduct were in fact the appropriate officials to authorize such activity. The FBI lias no interpretation responsibilities in this area.

137. See generally Marro, The F.B.I. Once Honored Its "Bag Jobs," N.Y. Times, May 1, 1977, § 4, at 1, col. 3; Korn and Craig, Making It all Perfectly Legal, Wash. Post, Jan. 20, 1974, \& C, at 1, col. 1 .

138. The "defense of superior orders" in American law is very similar to the reliance on an 


\section{bag" jobs, wiretapping and mail openings—although serious violations}

official interpretation of the law defense. See generally L. C. GReEN, Superior ORDERs IN NATIONAL AND INTERNATIONAL LAW 109-58, 301-17 (1976). In United States v. Calley, 22 U.S.C.M.A. 534, 48 C.M.R. 19 (1973), Lieutenant Calley was convicted of the premeditated nuurder of twenty-two infants, children, women and old inen and of assault with intent to nuurder a two-year-old child. The court held that obedience to an order of a snperior officer is not a defense to a war crime charge if the order was unlawful and its recipient knew that it was unlawful or a man of ordinary sense and understanding would have known, even if the actual recipient did not. Thus, both the superior orders and the rehance on an official interpretation of the law defense require an appropriate official, good faith, and a reasonable behef that the conduct is lawful.

Model Penal Code $\$ 3.03$ (P.O.D. 1962), provides, in pertinent part:

(1) Except as provided in Subsection (2) of this Section, conduct is justifiable when it is required or authorized by:

(a) the law defining the duties or functions of a public officer or the assistance to be rendered to such officer in the performance of his duties ....

....

(3) The justification offered by Subsection (1) of this Section apphes:

…

(b) when the actor believes his conduct to be required or authorized to assist a public officer in the performance of his duties notwithstanding that the officer exceeded his legal authority.

The "public duty" sections included in the proposed drafts of the federal criminal laws differ somewhat. Section 602 of the Brown Commission Report provides, in pertinent part:

(2) Directed by a Public Servant. A person who has been directed by a public servant to assist that public servant is justified in using force to carry out the public servant's direction, unless the action being taken by the public servant is plainly unlawful.

Section 1-3C3 of S. 1, 93rd Cong., 1st Sess., 119 Cong. Rec. 92 (1973), provides in part:

(b) Directed By a Public Servant.-It is a defense that conduct which wonld otherwise constitute an offense is engaged in by a person who has been requested by a public servant to assist him and who is carrying out the specific request of such public servant, unless such person acts in reckless disregard of the risk that the conduct was not required or authorized by law.

Section 521 of S. 1400, 93rd Cong., 1st Sess., 119 CoNG. REC. 9655 (1973), provides in part:

(a) Defense.-It is a defense to a prosecution under any federal statute that the defendant reasonably beheved that the conduct cliarged was required or authorized by law:

(1) to carry out his duty as a public servant, or as a person acting at the direction of a public servant. ...

Scction 541 of S.1, 94th Cong., 1st Sess., 121 CoNG. REc. 211 (1975), provides in part:

(a) DEFENSE.-It is a defense to a prosecution under any federal statute that the con-

duct charged was required or authorized by law:

(1) To carry out the defendant's authority as a public servant, or as a person acting at the direction of a public servant. . . .

Judge Leventhal concluded that the public duty defense of § 541 of S.1 (1975) was not applicable to Barker and Martinez because their conduct was neither required nor authorized. United States v. Barker, 546 F.2d at 966 n.37. On the other hand, one Justice Departinent attorney who liclped draft S. 1400 is of the opinion that "the "public duty" section probably wonld have served as an effective defense for the Cubans arrested in the Watergate complex; they conld credibly have claimed ignorance of United States law and sliown 'reasonable reliance' on the words of high government officials." Korn and Craig, Making It All Perfectly Legal, Wash. Post, Jan. 20, 1974, § C, at 1, col. 5 .

Senate Bill I437, 95th Cong., 1st Sess., 123 CoNG. REC. 19025 (1977), the most recent proposed draft of the federal criminal laws, does not contain a specific section providing a "public duty" defense, but instcad provides generally that the defeuse of exercise of public authority "shall be determined by the courts of the United States according to the principles of the common law as they may be interpreted in the light of reason and experience." Id. at $\$ 501$.

It is interesting to note that parts of Judge Wilkey's opinion appear to track the language of the "public duty" defense contained in $\$ 3.03$ of the Model Penal Code: "situations in which a government official enlists the aid of a private citizen to help him perforn a governmental task," 
of constitutional rights-are not comparable to mass murder and concentration camp atrocities. Surely a jury could not find that someone reasonably and in good faith beheved that such heinous crimes were lawful.

Recognizing a limited reliance on an official interpretation of the law defense does not undercut the rationale of the general mistake of law rule. The mistake of law rule is designed to encourage persons to know the law before acting, thus removing the incentive to remain ignorant. Persons who reasonably and in good faitlı seek authoritative interpretations of the law from the official charged with administering that law should not be penalized if that interpretation is later sliown to be incorrect. ${ }^{139}$

A limited rehance on an official interpretation of the law defense has an additional benefit when the potential criminal defendant is a public employee. Requiring that the person authorizing potentially illegal conduct be the "appropriate official" gives employees a firm basis to challenge questionable orders. ${ }^{140}$

\section{CONCLUSION}

Judges Wilkey and Merhige incorrectly held that the facts in Barker satisfied the requirements of the rehance on an official imterpretation of the law defense or the call-to-aid defense. Recognition of a

546 F.2d at 948; and "the public policy of encouraging citizens to respond ungrudgingly to the request of officials for help in the performance of their duties." Id. It appears that Judge Wilkey failed to cite $\S 3.03$ of the ModeI Penal Code and thereby raise the issue of the public duty defense because lie was very mucli concerned that Barker and Martinez be lield to the standard of both good faith and reasonableness which are required by the reliance on an official interpretation of the law defense but not by the public duty defense of the Model Penal Code.

The pubhic duty defense appears to be a way to avoid both the reasonableness and the appropriate official requirements of the reliance on an official interpretation of the law defense and the necessity requirement of the call-to-aid defense, and therefore slould not be adopted by Congress or recognized by the courts. Because the public duty defense does not require a slowing of reasonable behef in the legality of the acts, it is similar to the Nuremburg defenses and is open to the same criticisms.

139. Public einployees who receive orders through a conduit may rely on the defense if they believe in good faith that the appropriate official was the source of the orders-even if a reasonable person would have doubted that the appropriate official was in fact the source. Thus, had Hunt told Barker and Martinez that the President authorized the break-in, the defendants slould have been acquitted if a jury had found that Barker and Martinez believed Hunt's statement, and reasonably believed that the conduct was therefore lawful. See notes 114-119 supra and accompanying text.

140. It is not clear whether this limited defense adequately responds to Chief Judge Bazelon's concern expressed in Zweibon v. Mitchell, 516 F.2d 594, 679 n.12 (D.C. Cir. 1975) (concurring and dissenting opinion), cert. denied, 425 U.S. 944 (1976):

I think it would be unrealistic to suppose that employees of the Justice Departinent should be forced to choose between termination of employment for refusing to follow directives and mamtenance of a correct view of constitutional duties in opposition to the incorrect view of superiors. Civil disobedience within the Department is highly unlikely and we may doubt whether it should be encouraged. 
limited defense of reliance on an official interpretation of the law-for individuals who reasonably and in good faith rely on the appropriate government official-is consistent witl the policy goals of the general mistake of law rule. Allowing a limited defense also comports with notions of fairness because it is unjust to require someone to know more than the official charged with administering the law. To the extent that Barker holds that a mistake of law exception can be based on the apparent authority of a minor government official, however, the case paves the way for further official misconduct.

Stephen M. Kristovich*

* B.A. 1975, Stanford University; J.D. 1978, Boalt Hall School of Law. 
